\title{
Quantitative Definition of Seismic Performance Levels for Precast Bridge Piers with Continuous Reinforcement
}

\author{
Seongjun Park, ${ }^{1}$ Chandara Koem, ${ }^{1}$ and Changsu Shim $\mathbb{D}^{2}$ \\ ${ }^{1}$ Chung-Ang University, Seoul, Republic of Korea \\ ${ }^{2}$ School of Civil and Environmental Engineering, Urban Design and Studies, Chung-Ang University, Seoul, Republic of Korea \\ Correspondence should be addressed to Changsu Shim; csshim@cau.ac.kr
}

Received 17 September 2019; Revised 6 July 2020; Accepted 15 July 2020; Published 7 September 2020

Academic Editor: Agathoklis Giaralis

Copyright $(0) 2020$ Seongjun Park et al. This is an open access article distributed under the Creative Commons Attribution License, which permits unrestricted use, distribution, and reproduction in any medium, provided the original work is properly cited.

For construction sites within cities, which require fast construction because of restrictions in road occupation time, or for other occasions where construction period is an important factor because of similar reasons, application of a modular construction method using precast members is efficient in terms of shortening the construction period. The substructures of bridges are normally constructed using cast-in-place, which has been a major cause of delays in construction. Application of a modular construction method could decrease the occupation time in the sites. A prime example is the Accelerated Bridge Construction (ABC) by the Texas Department of Transportation (TDOT) and Federal Highway Administration (FHWA). Precast members are the key components of ABC. The main purpose of this paper is to provide clear seismic performance standards for precast bridge piers. Current seismic design codes require force-based design checks and provide qualitative evaluation of the overall structure. They do not provide specific qualitative criteria for individual structures with particular types. Previous research has been focused on reinforced-concrete bridge piers, while lacking on research towards prefabricated bridge piers with continuous reinforcements. In order to quantitatively evaluate the seismic performance level of prefabricated bridge piers, the seismic performance was quantitatively suggested in accordance with the classification of four which are operational, immediate occupancy, life safety, and collapse prevention. These criteria are cracking of cover concrete, crushing of cover concrete, yielding of axial steels, and fracture of axial steels. Based on the given seismic performance evaluation criteria, evaluation and verification were conducted on four prefabricated bridge piers with continuous reinforcement that have undergone quasistatic cyclic experiments. The momentcurvature analysis model was constructed for the parametric study and verified through experimental results. Based on the developed M-Phi model, prefabricated bridge piers with continuous reinforcement, which were designed force-based using response correction factor, were evaluated. In addition, parametric study was also conducted focusing on concrete strength, magnitude of prestress, and transverse reinforcement. Depending on the level of individual performance produced by ranges of these variables within possible runs on actual piers, the impact of 3 variables was analyzed. Furthermore, in response to changes in each variable, the impact on the relevant seismic performance level was verified through response spectrum analysis.

\section{Introduction}

For construction sites within cities, which require fast construction because of restrictions in road occupation time, or for other occasions where construction period is an important factor because of similar reasons, application of a modular construction method using precast members is efficient in terms of shortening the construction period. The substructures of bridges are normally constructed using cast-in-place, which has been a major cause of delays in construction.
Application of a modular construction method could decrease the occupation time in the sites; manufacture of standardized, factory-made segments has the benefit of ensuring the quality and efficiency of products and the safety of laborers at the same time. An example would be the development of a substructure system divided into segments for short- and medium-span bridge substructures, funded by the Texas Department of Transportation (TDOT) and Federal Highway Administration (FHWA) as part of the Accelerated Bridge Construction $(\mathrm{ABC})$ program [1]. 
An earthquake creates severe damage even if the structure has not collapsed, and such damage results in indirect social loss because of the considerable time and expense required for the recovery. The economic impact of this natural hazard has been analyzed in Los Angeles, and it has been stated that when important bridges have received severe damage, the overall cost, including maintenance cost, increases 11 times compared to cases where important bridges have not [2]. Because an earthquake creates a wide range of damage immediately from its occurrence, it does not provide sufficient time to devise a repair method based on proper evaluation of performance. For instance, after the Kobe earthquake in 1995, the management of the Hanshin Expressway made a decision to divide response depending on the degree of impact. In cases where a reinforced-concrete bridge pillar has not collapsed but still has more than $1.75 \%$ drift level of residual displacement, it will be demolished and then reconstructed. In the remaining cases with lesser drift levels, repair and reinforcement will be applied to the structures [3]. In terms of seismic design, this method aims to avoid instances where the bridges collapse because of brittle fracture, because such sudden damage deprives people of sufficient evacuation time. In order to prevent this kind of situation, sufficient ductility capacity is required. However, such ductility design tends to create a considerable permanent displacement, called residual displacement, after strong earthquakes, and for bridges built through this concept, it becomes difficult to properly determine the aftermath of the earthquake and the level of repair needed. As a solution to this, utilizing the concept of structural damage, which includes resilience in the design, will allow the bridge to be able to function even under a strong earthquake while minimizing the impact on the traffic condition during the bridge reconstruction. One important thing about self-centering, a significant index of resilience, is that it can also reduce the remaining damage on the main elements of bridges that have experienced earthquakes. A bridge pier with prestress is especially a notable option as its prestress allows a high level of recentering capability and wide range of energy absorption capacity.

Current design criteria for evaluation of seismic performance provide qualitative criteria on the overall bridge and lack attention on specific levels of performance, with regard to the quantitative condition, of a particular bridge type $[4,5]$. Evaluation of seismic design is an essential step in the design process, and because of differences in diameter, concrete strength, and combination of axial steels depending on the types of bridges, case-by-case approach is required. Within the scope of reinforced-concrete bridge piers, Sheikh has suggested cracking of cover concrete, yielding of reinforcements, crushing of cover concrete, and fracture of reinforcements as quantitative criteria for seismic performance. The seismic performance of reinforced-concrete bridge piers designed under the design codes of Canada and Australia has undergone evaluation and analysis [6, 7]. Criteria that divide the seismic performance of reinforcedconcrete bridge piers into 5 levels have been suggested and verified by Hose. Hose also defined levels of seismic performance with respect to the crack width of reinforced- concrete bridge piers and determined its final status of the bridge as the fracture of reinforcements [8]. Qualitative criteria for evaluation of seismic performance are yet to be provided for precast bridge piers with continuous reinforcement.

A quasistatic structural test on precast piers that have been constructed with combinations of axial steels consisting of continuous reinforcements and strands has been conducted by Shim $[9,10]$. The main variables of this precast bridge were intake of prestress, transverse reinforcement ratio, and axial steel ratio. For up to a maximum of $8.0 \% \mathrm{drift}$ level, there were no decreases in strength, while for low drift levels, index of resilience (self-centering) was confirmed. Meanwhile, with regard to precast bridge piers that have been constructed with a combination of strand, steel bar, and continuous reinforcements and had intermediate anchorage of prestressing steels applied, a quasistatic structural test has also been conducted. In terms of displacement ductility, these piers showed about $36-54 \%$ superiority over precast bridge piers that have been constructed with combinations of strands and continuous reinforcements [11]. A quasistatic structural test has also been conducted on precast piers that utilized debonded tendons and had high-strength shell structure applied to the first segment where the foundation and column meet. Compared to the previously tested precast bridge piers, these piers showed higher efficiency in terms of initial stiffness [12]. A qualitative evaluation method has been proposed for precast bridge piers with earthquake damage, and ways to repair and reinforce precast bridge piers with such damage have been researched $[13,14]$.

Column connections that serve as good candidates for $\mathrm{ABC}$ in moderate and high seismic regions include the following: mechanical bar coupler connections [15], pocket and socket connections [16-19], and rocking systems [20-26].

Current seismic design codes require force-based design checks and provide qualitative evaluation of the overall structure. They do not provide specific qualitative criteria for individual structures with particular types. This study provides qualitative criteria on levels of seismic performance of precast bridge piers that have been constructed with continuous reinforcement. For each aspect given by the main design codes, which are operational, immediate occupancy, life safety, and collapse prevention, a quantitative definition has been provided, i.e., cracking of cover concrete, yielding of axial steels, crushing of cover concrete, and fracture of axial steels. The given criteria have been applied on four specimens subjected to a quasistatic cyclic experiment for evaluation and verification. For analysis of the impact on full-scale piers as well as for variable interpretation, a moment-curvature analysis model was constructed. This model was verified by applying the four specimens on which the quasistatic cyclic experiment was conducted. Based on the developed M-Phi model, the seismic performance of prefabricated bridge piers with continuous reinforcement, which was designed force-based using response correction factor, was evaluated. Parametric analysis on compressive strength of cover concrete, magnitude of prestress, and transverse reinforcement ratio was also conducted. As for the range of design variables within the possible range of actual piers, corresponding analysis on the effect of 
three variables has been performed through response spectrum analysis. The effect on the corresponding level following the change in an individual factor has been verified.

\section{Qualitative Definition for Precast Bridge Piers with Continuous Reinforcement by Their Level of Seismic Performance}

This paper dealt with on seismic performance objectives from experimental data. During the seismic design process of the structure, it is required to be satisfied with the seismic performance objectives according to the structure grade in the design criteria. Seismic performance evaluation of structures is the same as the seismic performance objectives. In this paper, quantitative and qualitative criteria were clearly proposed for the seismic performance evaluation of precast bridge piers. It can be used not only for design, but also for the evaluation of existing structures.

Table 1 covers requirements for the performance of bridges, as provided by the main design codes (CAN/CSA-S6$06)$. Each requirement undergoes differential application depending on the return period (100, 500, and 2500 years), importance factor, and zone factor and is divided into 4 steps: operational, immediate occupancy, life safety, and collapse prevention. As covered in Table 1, seismic design criteria classify the recurrence periods of earthquakes, provide qualitative criteria on the entire structure, and suggest forcebased design of seismic performance for each structure. Criteria for quantitative evaluation of seismic performance have been partially applied only to particular bridge pier types. As shown in Table 2, the criteria are restricted only to reinforced-concrete piers, impact of limit states on the level of performance during runs, and availability of service after earthquake, following qualitative and quantitative explanations on performance and plans for restoration depending on the degree of damage [27, 28]. Sheikh has provided and evaluated quantitative criteria for seismic performance to apply on reinforced-concrete bridge piers that have undergone qualitative evaluation based on design criteria provided by Eurocode-8 [5], AASTHO [4, 29], Australia, and Canada $[6,30]$. These quantitative criteria have provided cracking of cover concrete, yielding of continuous reinforcement, crushing of cover concrete, and fracture of continuous reinforcement as quantitative standards and categorized them into 4 levels. Table 3 suggests cracking of cover concrete, yielding of exterior axial steels, crushing of cover concrete, and fracture of outer axial steel as quantitative code for precast bridge pier with continuous reinforcement, by its level based on the seismic quantitative performance code for overall bridge piers [14].

\section{Experimental Study with Qualitative Definition for Precast Bridge Piers with Continuous Reinforcement by Their Level of Seismic Performance}

3.1. Experiment on Precast Bridge Piers. For analysis according to the seismic performance code given in Table 3, four precast bridge pier specimens were constructed as shown in Figure 1(a) and a quasistatic experiment was conducted [31]. The characteristics of the four precast bridge piers specimens, which have been constructed with combinations of strands and continuous reinforcements (steel ratio: $1.45 \%$ ), are given in Table 4 . The main variables were the magnitude of prestressing force and spacing of transverse reinforcements [32]. PT1A, PT2A, and PT3A were designed under the condition where effective prestress was set to $43 \%-77 \%$, based on the yield strength of strand (ASTM A779 Grade 270, tensile strength: $1860 \mathrm{MPa}$, and yield strength: $1640 \mathrm{MPa}$ ). The axial load in Table 4 shows the sum of axial compressive force and additional magnitude of prestress needed to simulate the self-weight of the superstructure. Strands (diameter: $15.2 \mathrm{~mm}$ and nominal area: $138.7 \mathrm{~mm}^{2}$ ) were placed into 6 holes, with 3 strands for each hole (total nominal area of strand: $2496.6 \mathrm{~mm}^{2}$ ). Continuous axial reinforcing bars (diameter: $32 \mathrm{~mm}$ and nominal area: $794.2 \mathrm{~mm}^{2}$ ) were placed into 6 holes, with 1 bar for each hole (total nominal area of continuous axial reinforcement: $2496.6 \mathrm{~mm}^{2}$ ). Yield strength of continuous axial reinforcement was $400 \mathrm{MPa}$. T50 and T75 were constructed with the spacing of transverse reinforcement of bridge pier set to $50 \mathrm{~mm}$ (steel ratio: $2.68 \%$ ) and $75 \mathrm{~mm}$ (steel ratio: $1.80 \%$ ), respectively. The yielding strength of transverse reinforcement was $400 \mathrm{MPa}$. To check the concrete strength of the four specimens, four cylinders (D100 $\mathrm{mm} \times \mathrm{H} 200 \mathrm{~mm}$ ) were prepared under standard curing conditions. The compressive strengths of the cylinder specimens (T50PT1A, T75PT1A, T75PT2A, and T75PT3A) were $32 \mathrm{MPa}, 38 \mathrm{MPa}$, $35 \mathrm{MPa}$, and $36 \mathrm{MPa}$, respectively. The average compressive strength was $35 \mathrm{MPa}$ [33].

As given in Table 1, the four precast bridge pier specimens were each made with 3 segments, which were foundation, column, and pier cab, which were revised for transverse application. The column part was made with a circular solid section $800 \mathrm{~mm}$ in diameter. A chamfer detail was applied to lessen the stress concentration on the plastic hinge where the foundation and column meet. The effective length was $2750 \mathrm{~mm}$ from the loading point to the upper foundation (slenderness ratio: 3.44 ). To assemble the three segments, epoxy was spread on the joints and prestress was applied.

A quasistatic experiment on the four specimens was conducted under the experimental set-up shown in Figure 2. As shown in Figure 3, repetitive cyclic load was applied twice every cycle, with 1 cycle consisting of $400 \mathrm{~s}$. For measurement, crack gauge, displacement gauge, and strain gauge were attached according to the plan in Figure 4. To measure the whole displacement, DT01 gauge was attached. As for the rotation angle, DT02-DT03 was used for its calculation. The foundation was fixed to a strong floor, but in case of a slip, an additional displacement gauge was installed. To observe the opening gap at the joint of pier cap and column during the load application, a crack gauge was equipped. As for monitoring the condition of concrete, strain gauges were attached to its surface. To observe the effect of axial reinforcement, a displacement gauge was attached and grout was casted. Because of the difficulty in attaching the gauges to the 
TABLE 1: Performance requirements in CHBDC codes (CAN/CSA-S6-06).

\begin{tabular}{|c|c|c|c|}
\hline \multirow{2}{*}{ Return period } & \multicolumn{3}{|c|}{ Bridge } \\
\hline & Lifeline (type III) & Emergency route (type II) & Others (type I) \\
\hline Small to moderate earthquake (100-year RP) & $\begin{array}{c}\text { All traffic } \\
\text { Immediate use }\end{array}$ & $\begin{array}{c}\text { All traffic } \\
\text { Immediate use }\end{array}$ & $\begin{array}{c}\text { All traffic } \\
\text { Immediate use }\end{array}$ \\
\hline Design earthquake (500-year RP) & $\begin{array}{c}\text { All traffic } \\
\text { Immediate use }\end{array}$ & $\begin{array}{l}\text { Emergency vehicles } \\
\text { Immediate use }\end{array}$ & Repairable damage \\
\hline Large earthquake (2500-year RP) & $\begin{array}{l}\text { Emergency vehicles } \\
\text { Immediate use }\end{array}$ & Repairable damage & No collapse \\
\hline
\end{tabular}

TABLE 2: Qualitative and quantitative performance levels correlated with engineering parameters and repair techniques [27, 28].

\begin{tabular}{|c|c|c|c|c|c|}
\hline $\begin{array}{l}\text { Limit } \\
\text { states } \\
(\mathrm{LS}) \\
\end{array}$ & $\begin{array}{c}\text { Operational } \\
\text { performance } \\
\text { level }\end{array}$ & $\begin{array}{l}\text { Postearthquake } \\
\text { serviceability }\end{array}$ & Qualitative performance description & $\begin{array}{l}\text { Quantitative performance } \\
\text { description }\end{array}$ & Repair \\
\hline $1 \mathrm{~A}$ & & & No cracks & $\sigma c=f_{\mathrm{cr}}=0.4 \sigma \sqrt{f c}$ & No repair \\
\hline $1 \mathrm{~B}$ & $\begin{array}{c}\text { Fully } \\
\text { operational }\end{array}$ & Full service & $\begin{array}{l}\text { Few cracks that can be easily repaired } \\
\text { with no consequence on serviceability }\end{array}$ & $\sigma s=f_{\text {sy }}$ & $\begin{array}{l}\text { Limited epoxy } \\
\text { injection }\end{array}$ \\
\hline 2 & $\begin{array}{c}\text { Delayed } \\
\text { operational }\end{array}$ & $\begin{array}{c}\text { Limited service } \\
\text { (emergency vehicle } \\
\text { only) }\end{array}$ & $\begin{array}{l}\text { Initiation of inelastic deformation; } \\
\text { onset of concrete longitudinal cracks }\end{array}$ & $\begin{array}{c}\varepsilon_{c}=-0.004, \varepsilon_{s}=0.007 \\
\text { crack width }=2 \mathrm{~mm}\end{array}$ & $\begin{array}{l}\text { Epoxy injection; } \\
\text { concrete patching }\end{array}$ \\
\hline 3 & Stability & Closed & $\begin{array}{l}\text { Wide crack width/spalling over full } \\
\text { local mechanism regions; buckling of } \\
\text { main reinforcement; fracture of } \\
\text { transverse hoops; crushing of core } \\
\text { concrete; strength degradation }\end{array}$ & $\begin{array}{c}\mathcal{E}_{c}=\varepsilon_{c c 50} \text { (initial core } \\
\text { crushing) } \\
\varepsilon_{c}=\varepsilon_{\mathrm{cu}} \text { (fracture of } \\
\text { hoops) } \\
\varepsilon_{s}=\varepsilon_{\text {su }}=0.07 \\
\text { (longitudinal } \\
\text { reinforcement fracture) } \\
\varepsilon_{s}=\varepsilon_{\text {scr }} \text { (onset of } \\
\text { buckling) }\end{array}$ & $\begin{array}{l}\text { Extensive repair/ } \\
\text { reconstruction }\end{array}$ \\
\hline
\end{tabular}

$f_{c}=$ axial strain of concrete; $\varepsilon_{c c 50}=$ post-peak axial strain in concrete when capacity drops to $50 \%$ of confined strength; $\varepsilon_{c u}=$ ultimate strain of concrete; $\varepsilon_{s}=$ average tensile strain in longitudinal reinforcement, $\varepsilon_{\mathrm{su}}=$ tensile strain at fracture; $\varepsilon_{\mathrm{scr}}=$ steel strain at the onset of buckling of longitudinal bars.

TABLE 3: Qualitative and quantitative performance levels for precast bridge piers.

\begin{tabular}{|c|c|c|c|}
\hline Performance level & $\begin{array}{l}\text { Damage } \\
\text { level }\end{array}$ & $\begin{array}{l}\text { Qualitative performance } \\
\text { description }\end{array}$ & Quantitative performance description \\
\hline Operational & No repair & Fully operational & $\sigma c=f_{\mathrm{cr}}=0.4 \sigma \sqrt{f c}$ \\
\hline Immediate & $\begin{array}{l}\text { Minor } \\
\text { damage }\end{array}$ & $\begin{array}{l}\text { Short-term delayed operational } \\
\text { and recoverable }\end{array}$ & Yielding of the outermost for each axial steel type $\sigma_{s}=f_{\mathrm{sy}}$ or $\sigma_{\mathrm{ps}}=f_{\mathrm{py}}$ \\
\hline Life safety & $\begin{array}{c}\text { Partial } \\
\text { damage }\end{array}$ & $\begin{array}{l}\text { Long-term delayed operational } \\
\text { and recoverable }\end{array}$ & $\begin{array}{l}\text { Yielding of the outermost for each axial steel type and cover concrete } \\
\text { crushing }\left(\sigma_{s}=f_{\mathrm{sy}} \text { or } \sigma_{\mathrm{ps}}=f_{\mathrm{py}}\right) \text { and } \varepsilon_{c}=-0.003\end{array}$ \\
\hline $\begin{array}{l}\text { Collapse } \\
\text { prevention }\end{array}$ & $\begin{array}{l}\text { Major } \\
\text { damage }\end{array}$ & $\begin{array}{l}\text { Collapse prevention caused } \\
\text { extensive damage }\end{array}$ & Fracture of the outermost for each steel type $\sigma_{s}=f_{\mathrm{su}}$ or $\sigma_{\mathrm{ps}}=f_{\mathrm{pu}}$ \\
\hline
\end{tabular}

strand, strain compatibility method was used on the strain rate of the transverse reinforcement to calculate that of the strand.

3.2. Verification of the Quantitative Definition of Level of Seismic Performance. Figure 5 shows the load-displacement curve and envelope curve from each experiment. Table 5 summarizes the compared maximum loads and displacements for each specimen. Based on the results of the experiment, a minimum displacement ductility of 3.49 and ductility over $8 \%$ drift level without loss of strength could be confirmed. The strain compatibility method showed a difference of up to $14 \%$ with an average of $6.25 \%$. The results of this experiment could not verify the effect on the strand's magnitude of prestress because of inconsistencies in the concrete strength of each specimen. The results did prove that the chamfer detail delays the premature crushing of cover concrete [10].

Based on the given quantitative criteria for the evaluation of seismic performance in Table 3, Table 6 provides the displacement and load for each level. Figure 6 provides a summary of the values from Table 6 in load-displacement curves. Four levels are given in Table 3. The criterion for the 


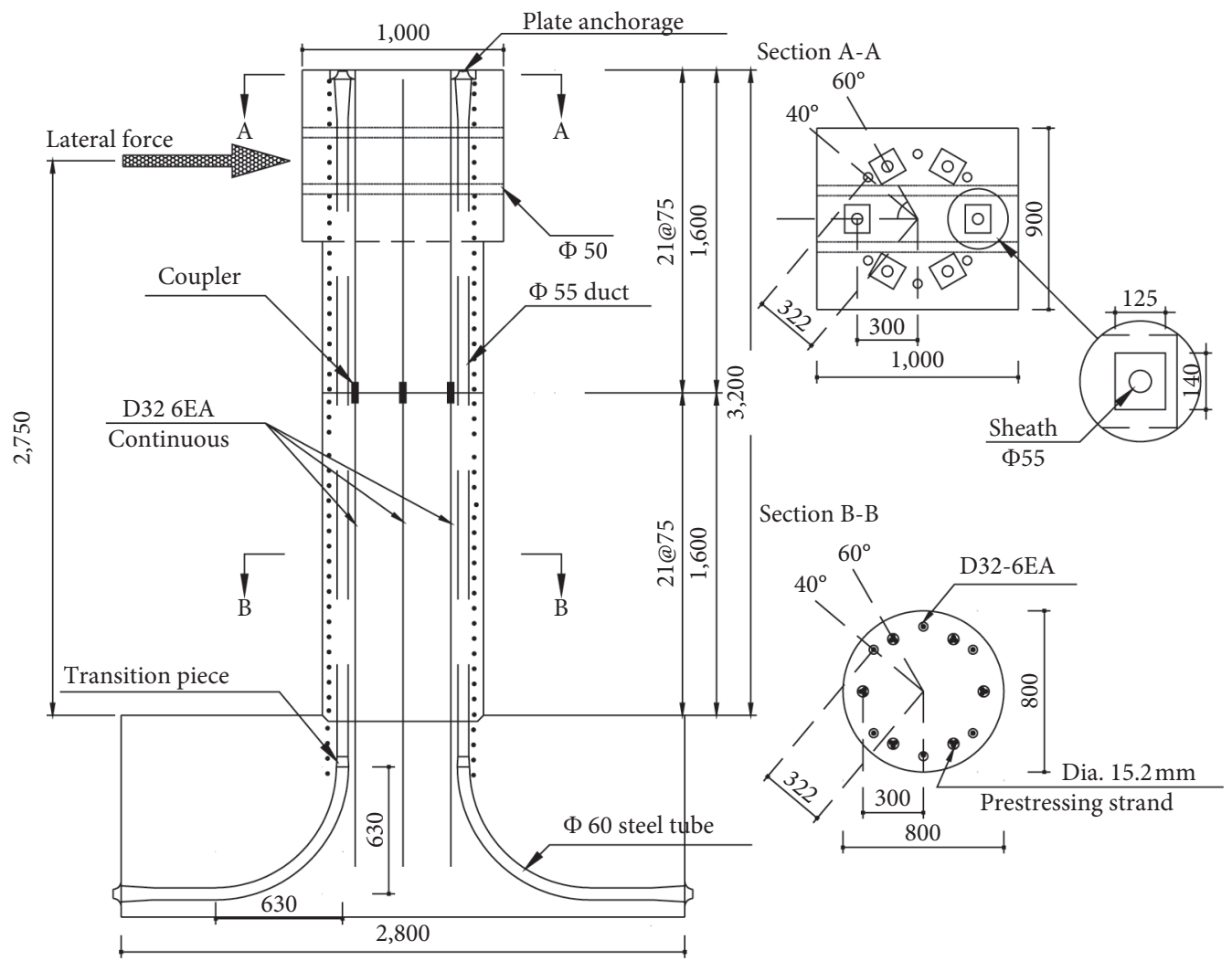

FIgURe 1: Specimen details (unit: $\mathrm{mm}$ ).

TABle 4: Test specimens.

\begin{tabular}{|c|c|c|c|c|c|c|c|}
\hline Specimen & $\begin{array}{l}\text { Concrete } \\
\text { strength } f_{\mathrm{ck}} \\
(\mathrm{MPa})\end{array}$ & $\begin{array}{l}\text { Number of } \\
\text { tendon EA }\end{array}$ & $\begin{array}{l}\text { Steel } \\
\text { ratio }(\%)\end{array}$ & $\begin{array}{l}\text { Transverse } \\
\text { reinforcement }\end{array}$ & $\begin{array}{c}\text { Effective } \\
\text { prestress } f_{\mathrm{pe}} \\
(\mathrm{MPa})\end{array}$ & $\begin{array}{c}f_{\mathrm{pe}} / f_{\mathrm{py}} \\
\text { ratio }(\%)\end{array}$ & $\begin{array}{c}\text { Axial load/compressive } \\
\text { strength of pier section (\%) }\end{array}$ \\
\hline T50PT1A & 32 & & & $\begin{array}{l}\mathrm{D} 16 @ 50 \mathrm{~mm} \\
(2.68 \%)\end{array}$ & & & 26 \\
\hline T75PT1A & 38 & 18@15.2 mm & 1.45 & $\begin{array}{l}\mathrm{D} 16 @ 75 \mathrm{~mm} \\
(1.80 \%)\end{array}$ & 1270 & 77 & 31 \\
\hline T75PT2A & 36 & & & 711 & 43 & 16 & \\
\hline T75РT3A & 35 & & & 918 & 56 & 22 & \\
\hline
\end{tabular}

first level, operational performance, was on whether the stress condition of cover concrete reached the cracking strength. Figures 7(a)-7(d) illustrate data on strains in ST02, ST03, and ST07 along with data on the applied force, while also providing the applied loads and displacements at each step. Gauges for ST02, ST03, and ST07 were placed $75 \mathrm{~mm}-225 \mathrm{~mm}$ above the upper surface of the foundation. In case the first crack occurs off the location of the gauge, the change in the gauge cannot be checked, thereby resulting in a delay in proper diagnosis (with respect to the actual time of its occurrence). As for the second standard, immediate occupancy, the criterion was on whether the stress condition of the outer axial steel reached the yield strength of continuous reinforcement or strand. In the case of this experiment, there are 2 combinations of axial steels. For each axial steel, the outer one was analyzed. The results of the measured responses of gauges ST10, ST11, ST12, and ST13 placed on the continuous reinforcing bars are given in Figures $7(\mathrm{e})-7(\mathrm{~h})$. The value indicated by the red dotted line was calculated by dividing the distance between the upper foundation and location of applied force $(2750 \mathrm{~mm})$ by the distance toward the location of the gauge and multiplying the result by the yield strain of continuous reinforcement. The first time of its arrival is given along with the positive and negative directions. For the yielding of the outer tendon, the strain compatibility method as illustrated in Figure 7(i) was used to calculate the yield strain of the strand. For all four specimens, the outer strand was the first to reach the yielding, and this was defined as the second criterion for the performance. The criterion for the third level, life safety, is on the crushing of cover concrete. The time of its spalling was defined as the point when the strain of concrete reached the ultimate strain. In the experiment, the strain gauge was lost when the cover concrete spalled. Because of this, the 


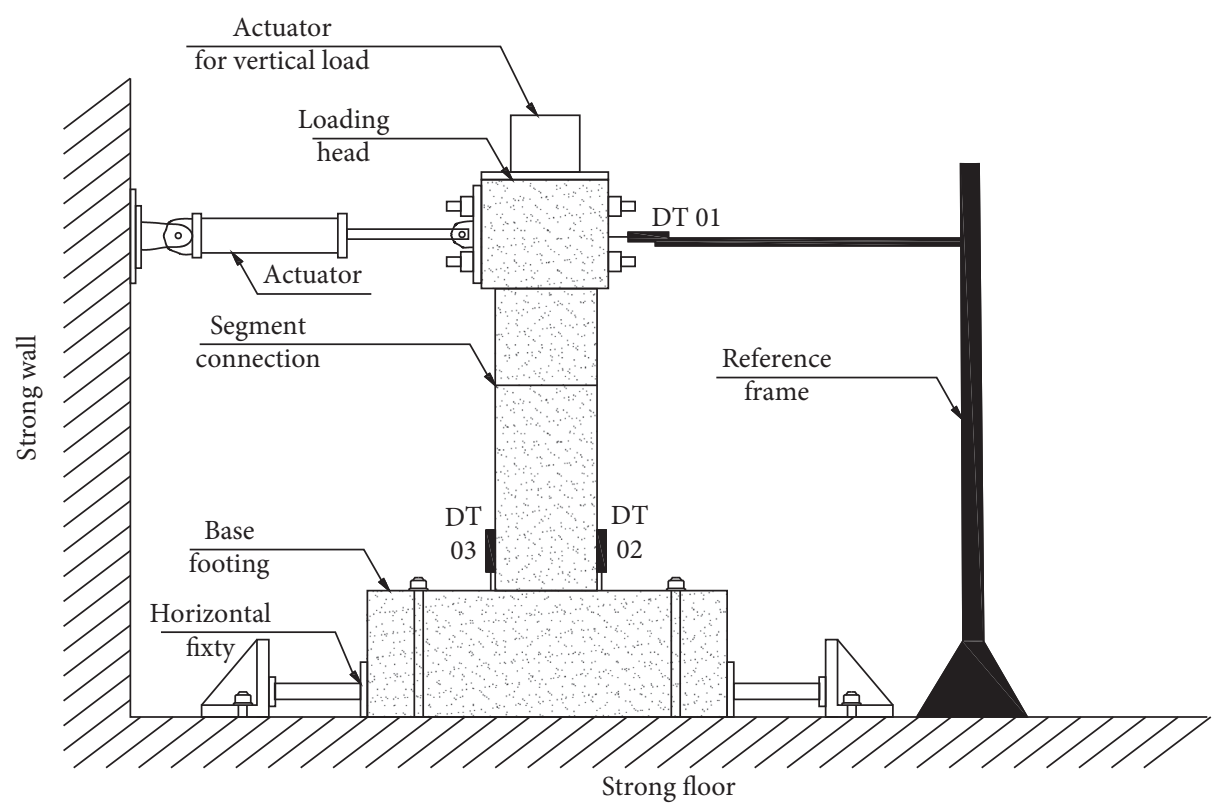

Figure 2: Test set-up.

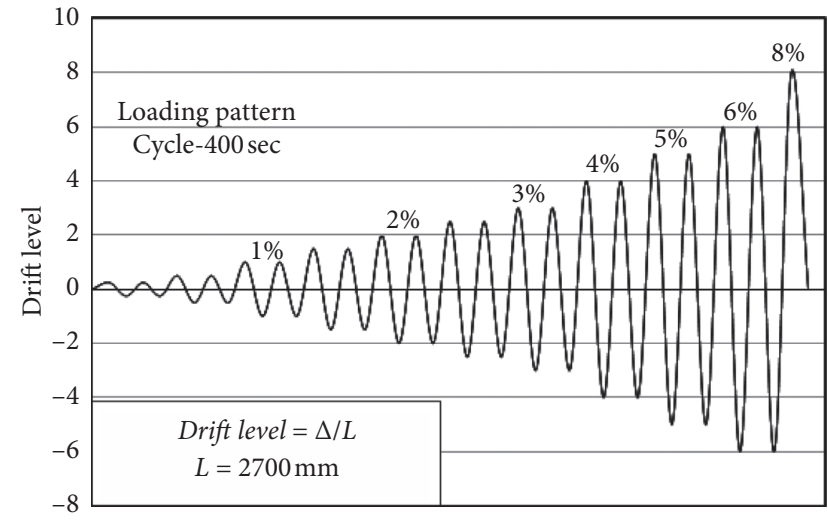

FIgURE 3: Loading pattern.

level was defined based on the visual observation given in Figures $7(\mathrm{j})-7(\mathrm{~m})$. In the case of collapse prevention, available displacement of the actuator used in the experiment was applied, but collapse was not reached.

T75PT1A had 34\% higher prestress applied, and while the effect of level 1 in the negative direction is unconfirmed, level 1 was reached $24.8 \%$ early in terms of strength under the positive direction. This result could not confirm the effect of level 2. Under the positive direction, the effect of level 3 could not be verified, while under the negative direction, level 3 was reached by T75PT1A $11.8 \%$ early compared to T75PT2A in terms of strength. T50PT1A had transverse reinforcement $25 \mathrm{~mm}$ more close-spaced than that of T75PT1A. The impact of levels 1 and 3 could not be verified for both positive and negative directions. Meanwhile, the effects on the time point of crack and crushing of concrete differed. The time of the outer strand yielding in T50PT1A was earlier than that of T75PT1A, with its degree being between $8.8 \%$ and $15.4 \%$. A more close-spaced transverse reinforcement resulted in an earlier arrival in level 2.

\section{Evaluation of Seismic Performance through Analysis of Precast Bridge Pier with Continuous Reinforcement}

4.1. Moment-Curvature Analysis. Following the concept shown in Figure 8, a moment-curvature analysis based on the strain compatibility method was conducted on the four specimens used in the quasistatic experiment. Confined and unconfined models for analysis were produced from the material models of Eurocode 2 and are shown in Figures 9(a) and 9 (b). Material models for reinforcement and strand were also from Eurocode 2 and are shown in Figures 10(a) and 10(b). As shown in Figure 11, each part was composed of 4 components, and based on the center line of transverse reinforcement, the inner concrete was defined as confined concrete, and the outer as unconfined concrete. The concrete part $(800 \mathrm{~mm}$ in diameter) was divided into layers with heights of $2 \mathrm{~mm}$ each, resulting in 400 small parts. The noncontinuous reinforcement installed for the construction of individual segments was not included in the calculation. For continuous reinforcement, ones, with height of $400 \mathrm{~mm}$ and $154 \mathrm{~mm}$ each, were placed with spacings following the measurement of 2D32 (D32:As $\left.=794 \mathrm{~mm}^{2}\right)$. Meanwhile, $15.2 \mathrm{~mm}$ strands (SWPC 7A $15.2 \mathrm{~mm}$ : As $=138.7 \mathrm{~mm}^{2}$ ) were situated at $700 \mathrm{~mm}, 550 \mathrm{~mm}, 250 \mathrm{~mm}$, and $100 \mathrm{~mm} \mathrm{(3}$ strands for each layer), and at the center, 6 strands were placed.

At the introduction of prestress, the continuous reinforcement was not grout-filled, so the prestress only took account of strands and confined and unconfined concrete. For the definition of the initial strain of each of the components, an axial force of $1000 \mathrm{kN}$, considering the self- 


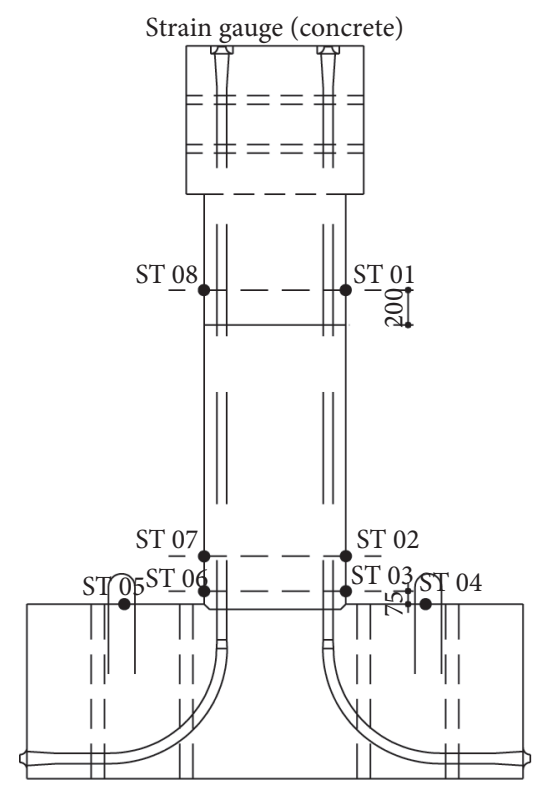

$\Omega$ Displacement transducer (crack)

- Displacement transducer

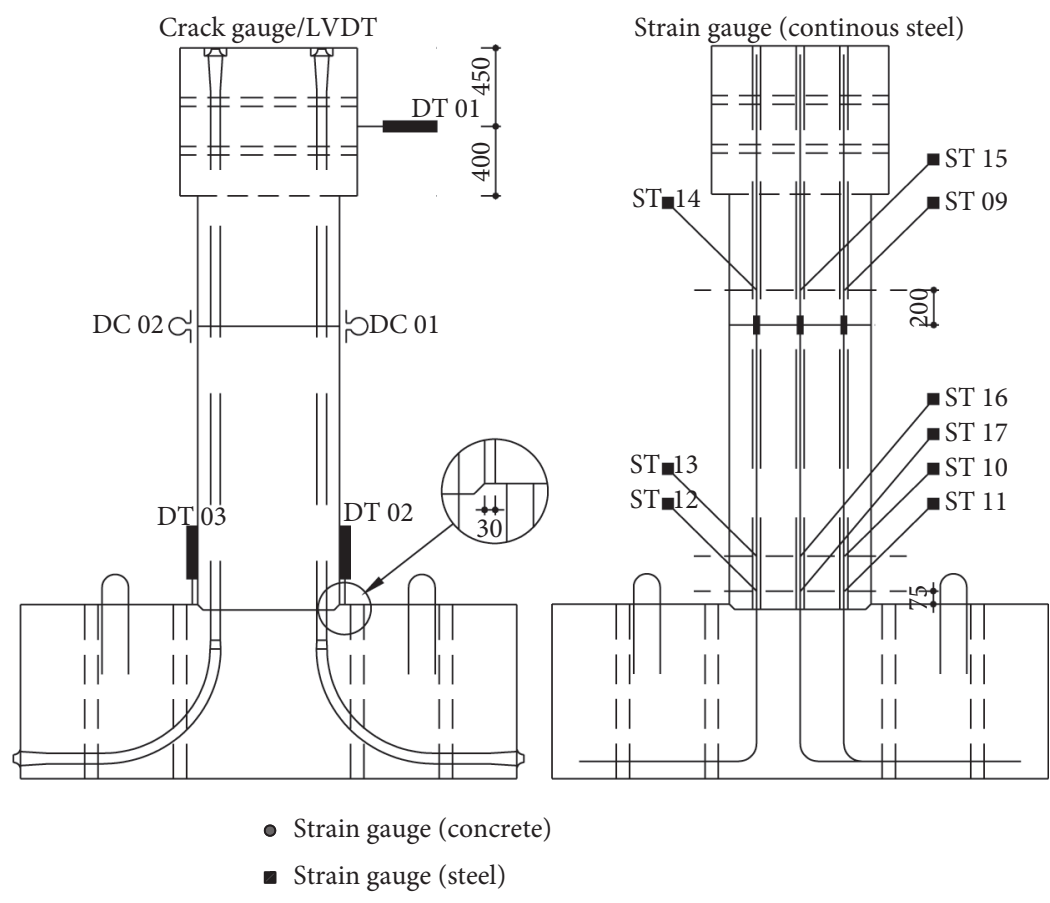

Figure 4: Measurement (unit: $\mathrm{mm}$ ).

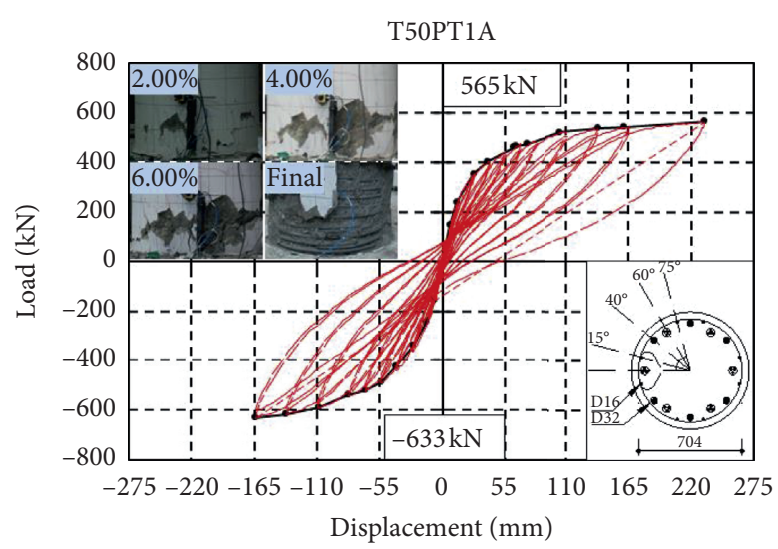

(a)

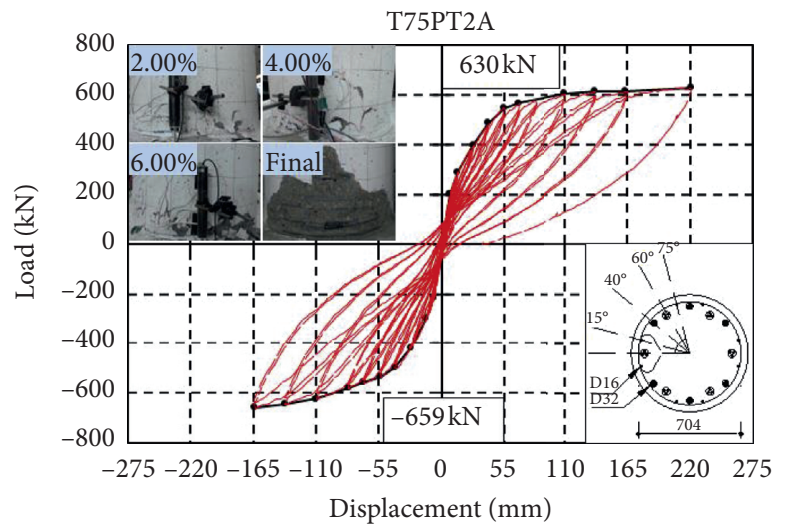

(c)

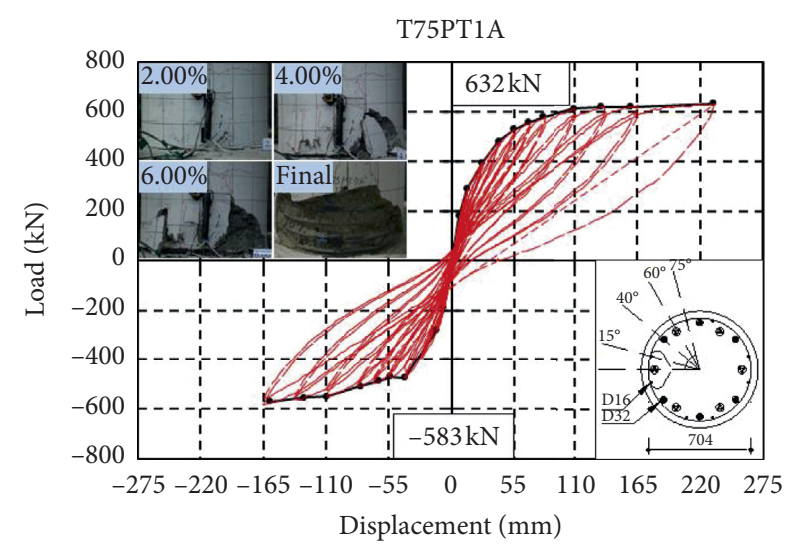

(b)

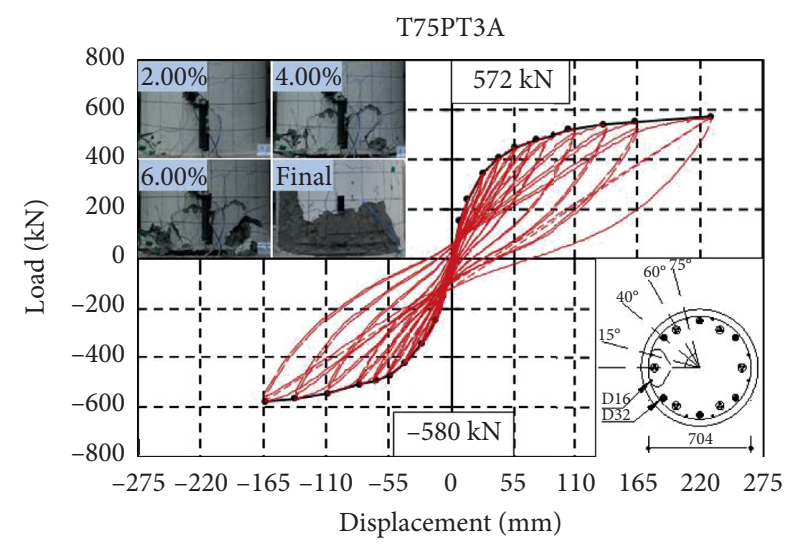

(d)

Figure 5: Load-displacement curves. (a) T50PT1A. (b) T75PT1A. (c) T75PT2A. (d) T75PT3A. 
Table 5: Maximum loads and displacements of test result.

\begin{tabular}{|c|c|c|c|c|c|c|c|c|c|}
\hline \multirow[t]{2}{*}{ Specimen } & \multirow{2}{*}{$\begin{array}{l}\text { Effective prestress } \\
f_{\mathrm{pe}}(\mathrm{kN})\end{array}$} & \multicolumn{5}{|c|}{ Maximum value ( + and - sign means left and right direction of displacement) } & \multicolumn{3}{|c|}{$\begin{array}{c}\text { Calculation value } \\
\text { (strain compatibility } \\
\text { method) }\end{array}$} \\
\hline & & $\begin{array}{c}\text { Load } \\
(\mathrm{kN}),(1)\end{array}$ & $\begin{array}{l}\text { Displacement } \\
(\mathrm{mm})\end{array}$ & $\begin{array}{c}\text { Load } \\
(\mathrm{kN}),(2)\end{array}$ & $\begin{array}{l}\text { Displacement } \\
(\mathrm{mm})\end{array}$ & $\begin{array}{l}\text { Displacement } \\
\text { ductility }\end{array}$ & $\begin{array}{c}\text { Load } \\
(\mathrm{kN}),(3)\end{array}$ & $\begin{array}{c}(3) / \\
(1)\end{array}$ & $\begin{array}{l}(3) / \\
(2)\end{array}$ \\
\hline T50PT1A & 1270 & -583 & -165 & 632 & 232 & More than 4.18 & 632 & 0.92 & 1.00 \\
\hline T75PT1A & 1270 & -633 & -165 & 565 & 231 & More than 3.49 & 555 & 1.14 & 1.02 \\
\hline T75PT2A & 711 & -659 & -165 & 630 & 220 & More than 4.45 & 587 & 1.12 & 1.07 \\
\hline T75PT3A & 918 & -580 & -165 & 572 & 230 & More than 3.66 & 596 & 0.97 & 0.96 \\
\hline
\end{tabular}

TABLE 6: Test result based on the proposed seismic evaluation criteria.

\begin{tabular}{cccccccccc}
\hline & & & \multicolumn{3}{c}{ Test } & \multicolumn{2}{c}{} \\
& \multicolumn{2}{c}{ Concrete cracking } & \multicolumn{2}{c}{ Reinforcement yielding } & \multicolumn{2}{c}{ Tendon yielding } & \multicolumn{2}{c}{ Cover concrete spalling } \\
& $\begin{array}{c}\text { Displacement } \\
(\mathrm{mm})\end{array}$ & $\begin{array}{c}\text { Load } \\
(\mathrm{kN})\end{array}$ & $\begin{array}{c}\text { Displacement } \\
(\mathrm{mm})\end{array}$ & $\begin{array}{c}\text { Load } \\
(\mathrm{kN})\end{array}$ & $\begin{array}{c}\text { Displacement } \\
(\mathrm{mm})\end{array}$ & $\begin{array}{c}\text { Load } \\
(\mathrm{kN})\end{array}$ & $\begin{array}{c}\text { Drift } \\
(\%)\end{array}$ & $\begin{array}{c}\text { Displacement } \\
(\mathrm{mm})\end{array}$ & $\begin{array}{c}\text { Load } \\
(\mathrm{kN})\end{array}$ \\
\hline \multirow{2}{*}{ T50PT1A } & -3.34 & -83.22 & -39.8 & -435.4 & -18.17 & -293.42 & 2.00 & -53.94 & -490.90 \\
& 2.78 & 62.24 & 52.4 & 438.1 & 23.16 & 330.84 & 2.00 & 62.73 & 459.46 \\
\hline \multirow{2}{*}{ T75PT1A } & -2.32 & -79.04 & -34.3 & -440.5 & -20.09 & -346.88 & 2.00 & -53.57 & -473.70 \\
& 2.18 & 63.50 & 53.8 & 526.5 & 21.87 & 362.76 & 2.00 & 54.75 & 529.98 \\
\hline \multirow{2}{*}{ T75PT2A } & -1.88 & -79.9 & -35.4 & -476.0 & -19.31 & -354.54 & 2.00 & -53.56 & -537.36 \\
& 2.475 & 83.76 & 45.8 & 509.7 & 22.91 & 366.10 & 2.00 & 54.87 & 545.90 \\
\hline \multirow{2}{*}{ T75PT3A } & -2.82 & -80.08 & -43.5 & -426.8 & -14.16 & -248.68 & 2.00 & -54.44 & -475.94 \\
& 2.79 & 71.32 & 26.2 & 340.1 & 18.02 & 278.92 & 2.00 & 55.16 & 447.40 \\
\hline
\end{tabular}

weight of the superstructure and applied prestress, was taken into account. As the top load was introduced after the grout had filled, it was divided and applied to the four material models. The load sharing ratio was distributed based on each material property (according to Figure 8), and by dividing by the area of each part, the initial strain was calculated.

Moment-curvature analysis process was done based on the strain compatibility method. Strain values defined in Figure 9 and material curves in Figure 10 were applied to derive the stress of each component. Regarding individual curvature $\phi$ of Figure 8, c, which was the distance between upper surface and neutral axis, and $\varepsilon_{\max }$ were derived. The strain of each layer was calculated as well. Summing the calculated strain and initial strain, the stress condition was derived from Figures 9 and 10, and the initial stress condition was removed. For each material, the stress condition for each layer was multiplied by the area of the corresponding layer. $\mathrm{C}$, an assumed distance towards the neutral axis, was constantly changed to maintain the sum of compressive force and tension force to 0 . The strength of section at that time was set by multiplying the distance between a point of action for compressive load consisting of $C_{1}+C_{2}+C_{3}+C_{4}+C_{5}+C_{6}+\ldots+C_{n}$ at the current state and a point of action for tension load consisting of $T_{1}+$ $T_{2}+T_{3}+T_{4}+T_{5}+T_{6}+\ldots+T_{n}$ with compressive or tension force. Moment-curvature curve was extracted by continuously increasing the curvature $\phi$. The load was calculated by dividing the moment with $2750 \mathrm{~mm}$ (distance towards the point of action) by its step, and $\phi$ was used to calculate displacement. To derive EI for each step, c was multiplied by $\mathrm{M}$ (moment) $/ \varepsilon_{\max }$, and corresponding displacement $\Delta$ was achieved through $\mathrm{PL}^{3} / 3 \mathrm{EI}$.
Through the derived values, load-displacement curve was obtained and underwent quantitative evaluation according to the codes shown in Figure 3. Comparing the analysis values with the experimental values, the results are given in Table 7 and are shown in Figures 12(a)-12(d). The analysis values have errors of $35.7 \%, 14.6 \%$, and $5.3 \%$ for levels 1, 2, and 3, respectively (based on the experimental values). For level 2, it is defined as the yielding point of axial steels. Because the gauge is attached $200 \mathrm{~mm}$ above the foundation, and not between the basement and column, the point of yielding is expected to be delayed compared to that of an actual case. For level 3, it is defined as the crushing of cover concrete. When it reaches the corresponding strain, the malfunction of strain rate gauge occurs, so in this case the diagnosis may be delayed.

4.2. Verification of the Quantitative Definition of Level of Seismic Performance. As shown in Figure 13, the loaddisplacement envelope curves were obtained through the M-Phi analysis. T75PT1A had prestress introduced 34\% higher than T75PT2A. Level 1 was reached by T75PT2A $41.0 \%$ earlier than T75PT1A. Level 2 was reached by T75PT1A 26.8\% earlier than T75PT2A. Level 3 was reached by $\mathrm{T} 75 \mathrm{PT} 1 \mathrm{~A} 10.2 \%$ earlier than T75PT2A. Level 4 was reached by $\mathrm{T} 75 \mathrm{PT} 1 \mathrm{~A} 5.0 \%$ earlier than T75PT2A. A tendency to reach level 1 earlier was observed when prestress decreases. Meanwhile, when prestress increases, a tendency to reach levels 2, 3, and 4 earlier was demonstrated.

T50PT1A had transverse reinforcement $25 \mathrm{~mm}$ more closely spaced than T75PT1A. Level 1 was reached by T50PT1A 18.1\% earlier than T75PT1A. Level 2 was reached 


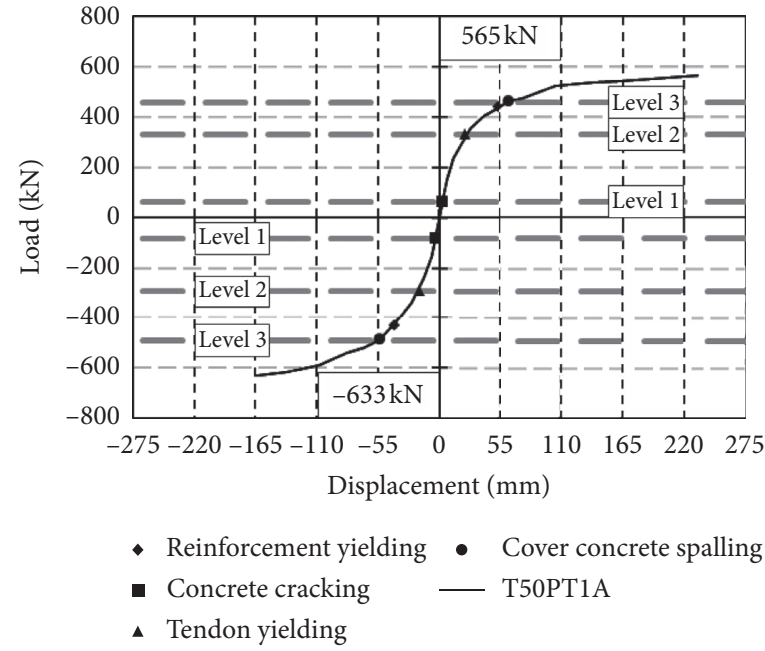

(a)

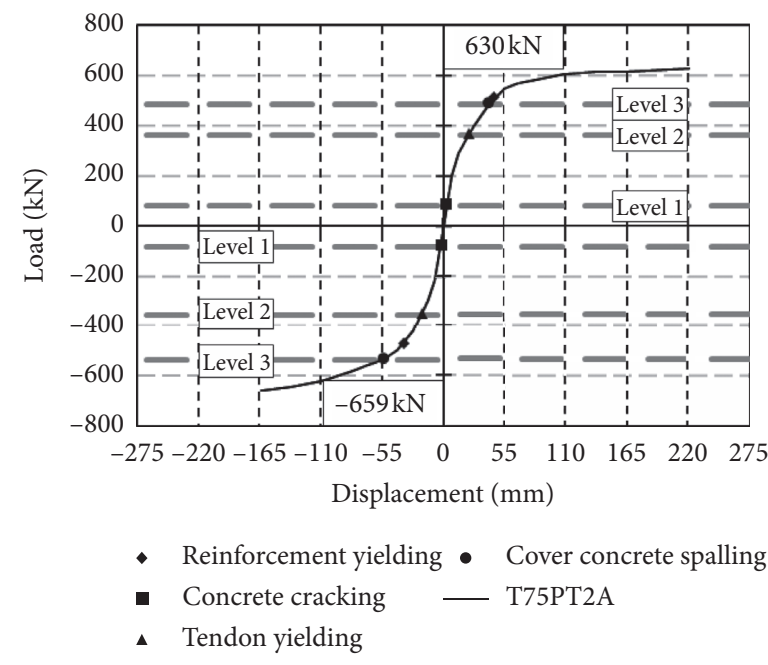

(c)

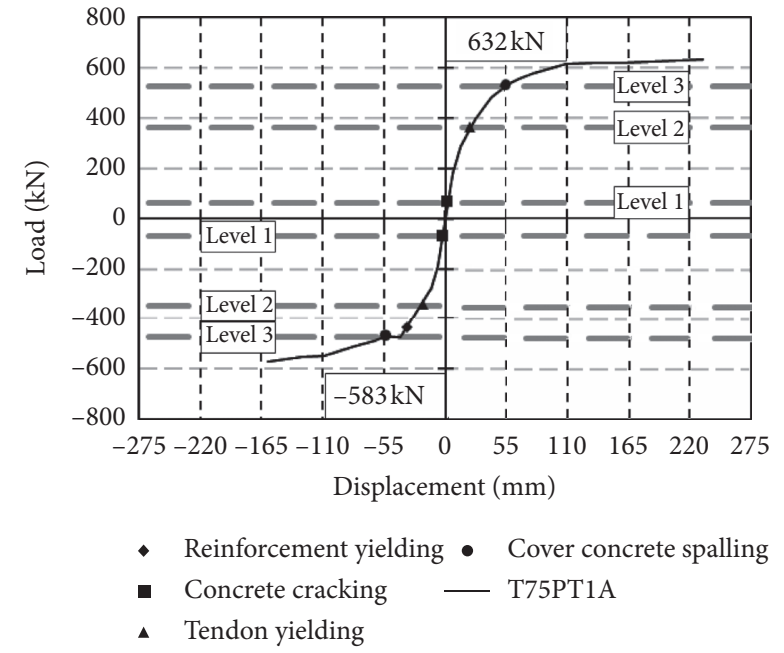

(b)

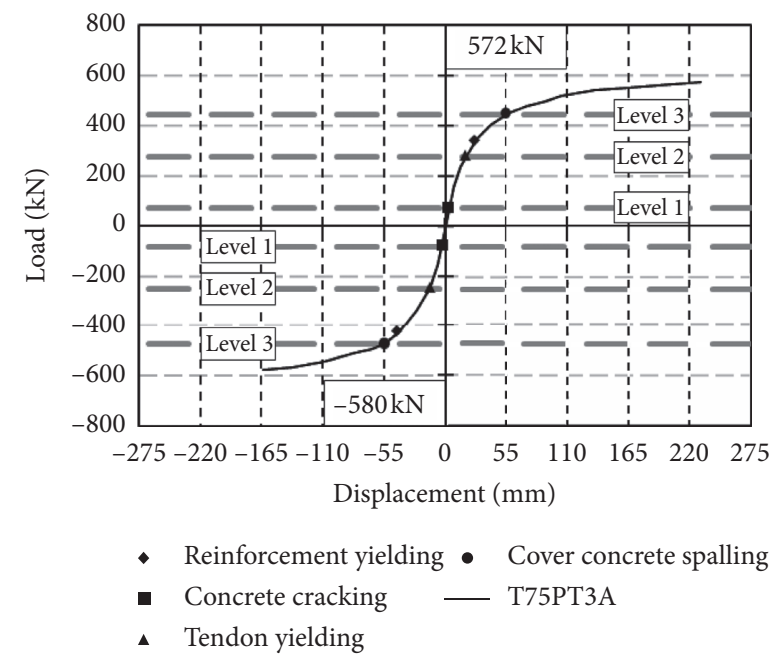

(d)

Figure 6: Load-displacement envelope curves according to performance levels. (a) T50PT1A. (b) T75PT1A. (c) T75PT2A. (d) T75PT3A.

by T50PT1A $10.0 \%$ earlier than T75PT1A. Level 3 was reached by T50PT1A $8.3 \%$ earlier than T75PT1A. Level 1 was reached by T50PT1A $0.3 \%$ earlier than T75T1A.

\section{Precast Bridge Pier Design by Defined Seismic Performance Level}

5.1. Evaluation of Full-Scale Designed Precast Bridge Pier. Seismic design of bridge pier is made to prevent collapse from earthquake, and it is achieved through study of failure mechanism. This mechanism is determined by the order of pier and joint yielding. The column zone is designed to act as plastic hinge to provide ductile failure mechanism [34]. For a full-scale parametric study, precast bridge pier with a combination of continuous reinforcement and strand designed force-based using response modification factor was constructed. This bridge was designed as a superstructure of steel box and pile foundation. The ranks of pier, earthquake, and seismic zone were all 1 . The risk coefficient was 1.4 and seismic zone factor was 0.11 . T-type precast bridge pier with a height of $6.511 \mathrm{~m}$ and a diameter of $2.2 \mathrm{~m}$ was designed; Figure 14 shows its section. The axial steel combination consists of strand and continuous reinforcement; the ratio of reinforcement was $5.72 \%$. Strands with an outer diameter of $15.2 \mathrm{~mm}$ and a cross-sectional area of $138.7 \mathrm{~mm}^{2}$ were placed in 8 holes. For each of the holes, 19 strands were placed, the total used being 162 strands (total nominal area: $21082.4 \mathrm{~mm}^{2}$ ). This strand has a yield strength of $1640 \mathrm{MPa}$, ultimate strength of $1860 \mathrm{MPa}$, and coefficient elasticity of $200,000 \mathrm{MPa}$. Continuous reinforcements with a diameter of $32 \mathrm{~mm}$ and a sectional area of $794.2 \mathrm{~mm}^{2}$ were distributed into the 8 holes. This reinforcement has a tension strength of $400 \mathrm{MPa}$ and a coefficient elasticity of $200,000 \mathrm{MPa}$. Transverse reinforcements of $16 \mathrm{~mm}$ were placed with spacing of $80 \mathrm{~mm}$ in the plastic hinge region and $300 \mathrm{~mm}$ for the other regions. The summation of superstructure reactions and self-weight of bridge pier (unit weight: $25 \mathrm{kN} / \mathrm{m}^{3}$ ) was $7,209 \mathrm{kN}$. Numbers behind PT, CK, and S express the 

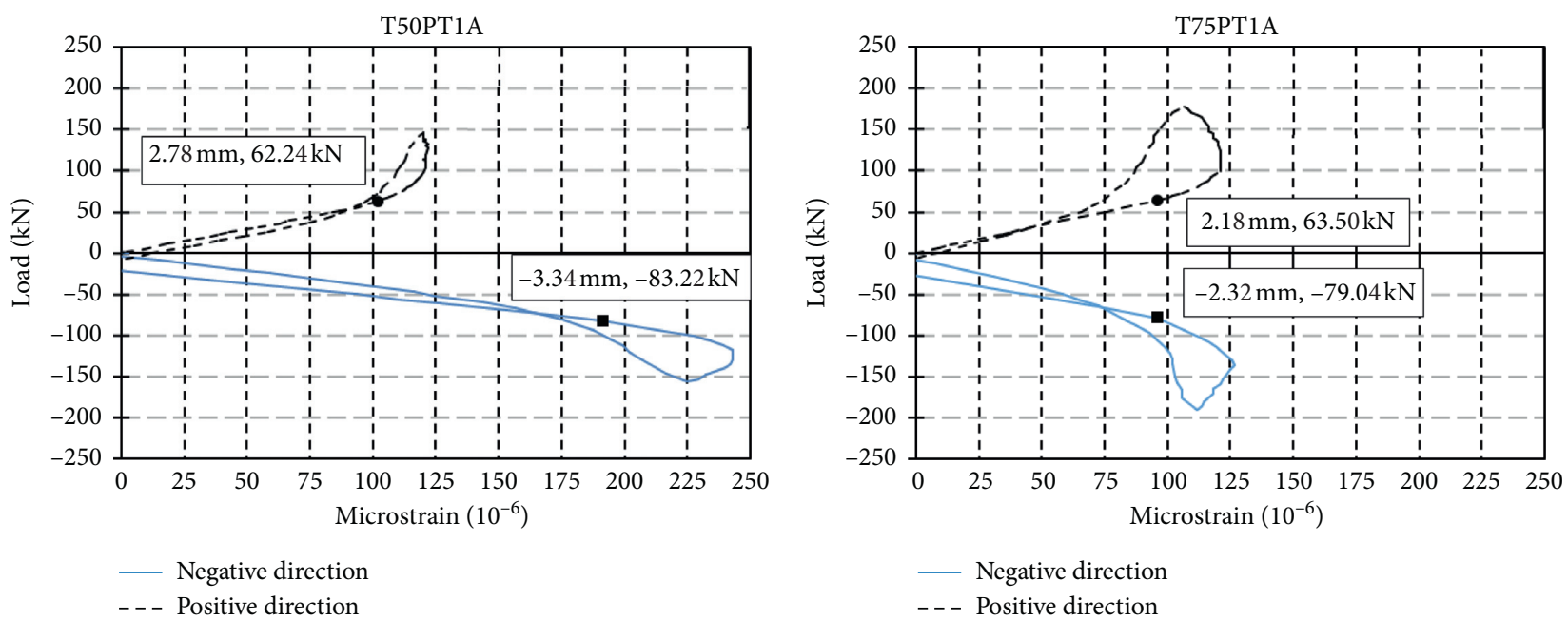

(a)

(b)
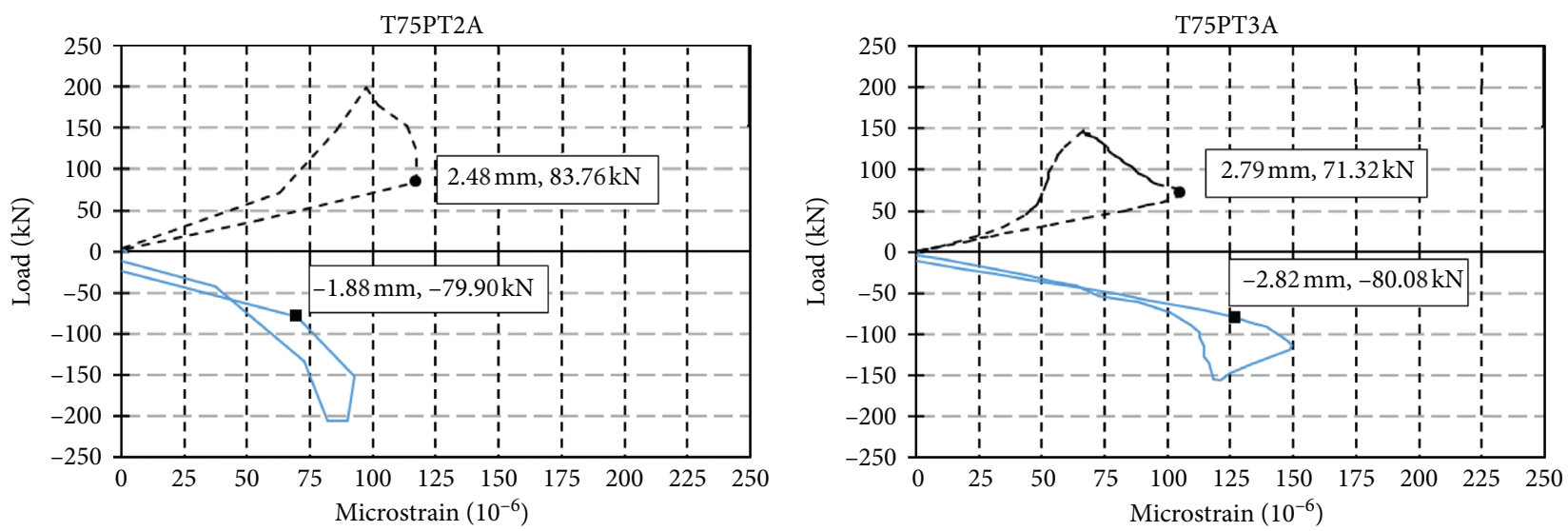

- Negative direction

- Negative direction

- - - Positive direction

- - - Positive direction

(c)

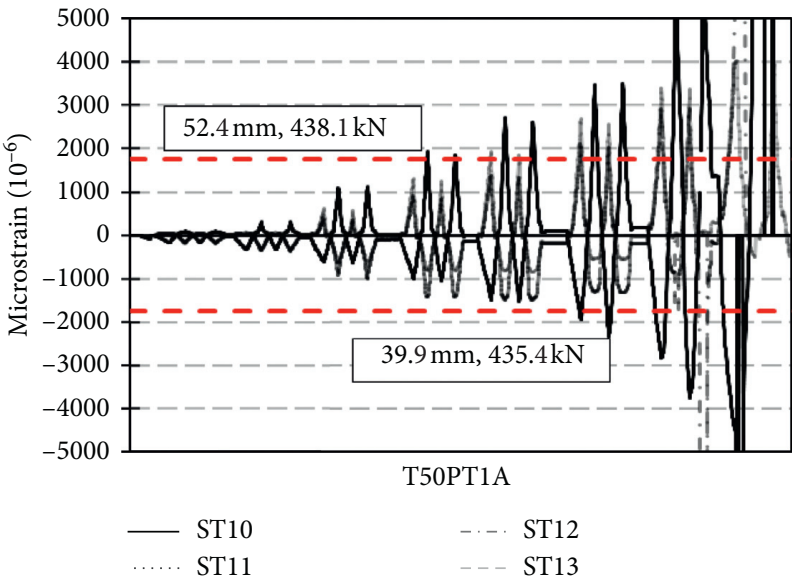

(d)

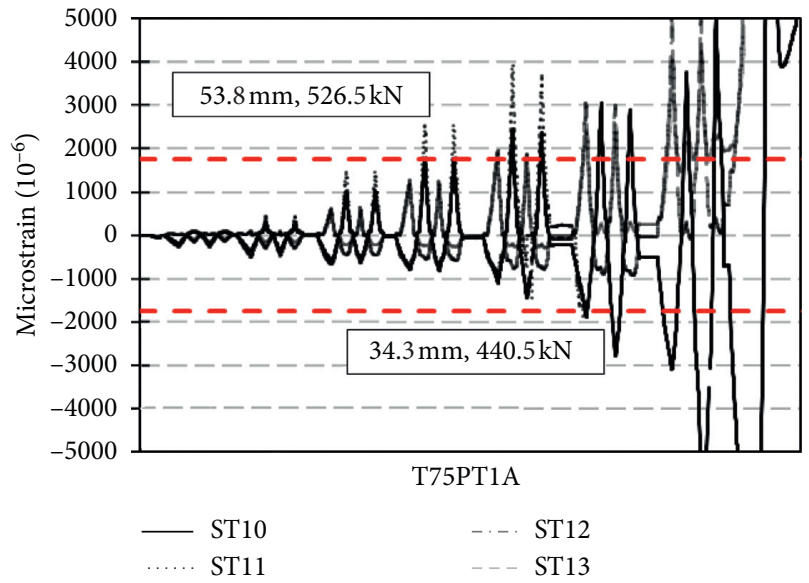

(e)

Figure 7: Continued. 


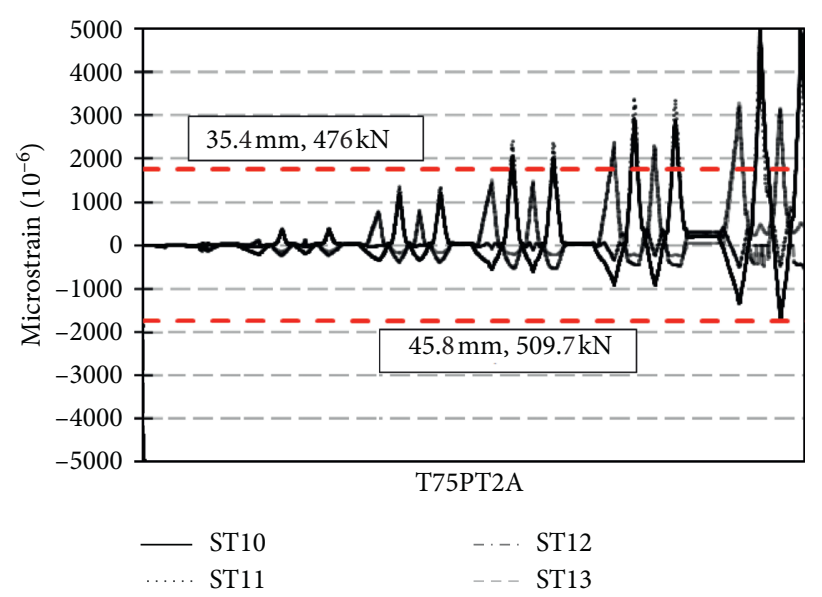

(g)

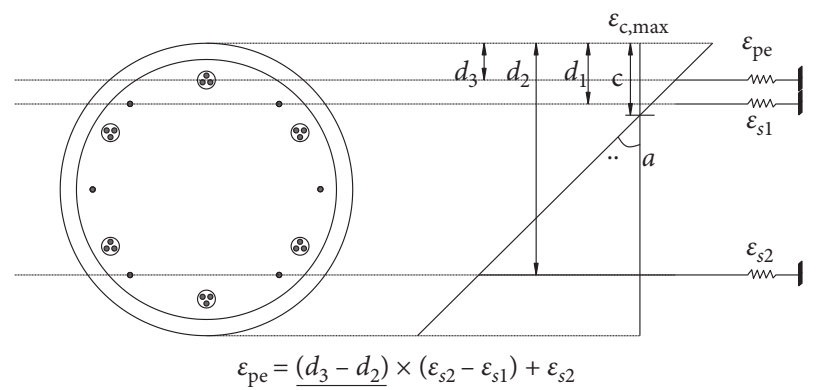

(i)

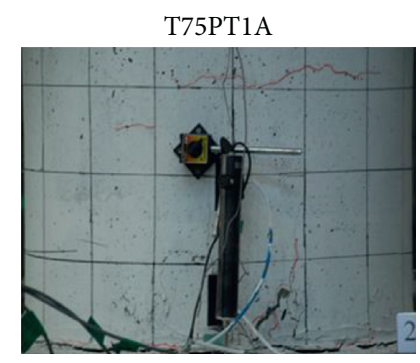

(k)

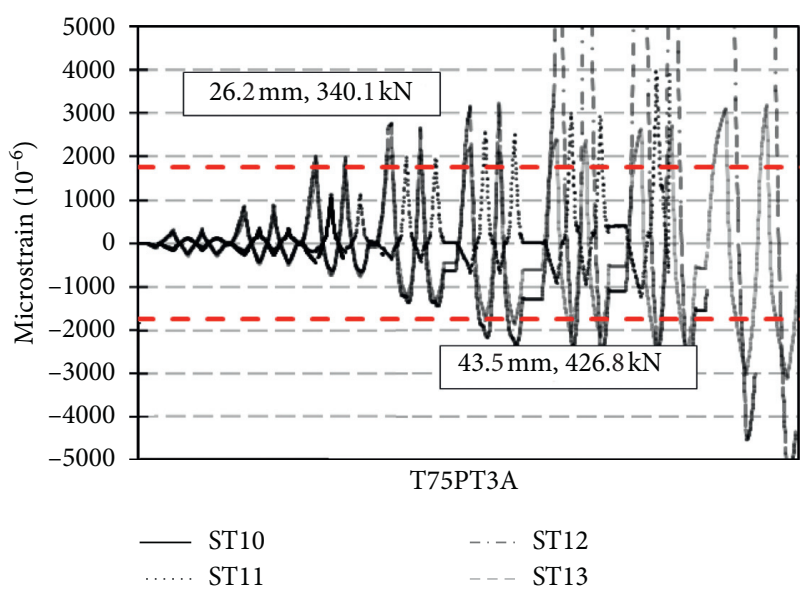

(h)

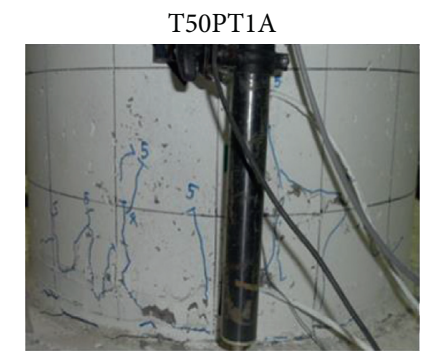

(j)

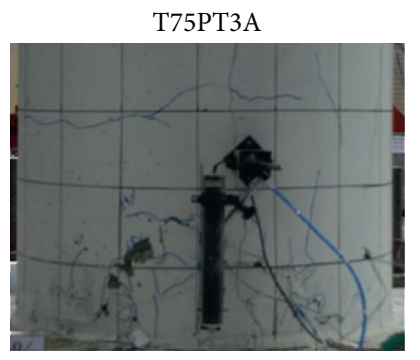

$(\mathrm{m})$

Figure 7: Evaluation according to seismic performance levels. (a) Performance level 1 T50PT1A. (b) Performance level 1 T75PT1A. (c) Performance level 1 T75PT2A. (d) Performance level 1 T75PT3A. (e) Performance level 2 T50PT1A for reinforcement. (f) Performance level 2 T75PT1A for reinforcement. (g) Performance level 2 T75PT2A for reinforcement. (h) Performance level 2 T75PT3A for reinforcement. (i) Performance level 2 for tendon. (j) Performance level 3 T50PT1A. (k) Performance level 3 T75PT1A. (l) Performance level 3 T75PT2A. (m) Performance level 3 T75PT3A.

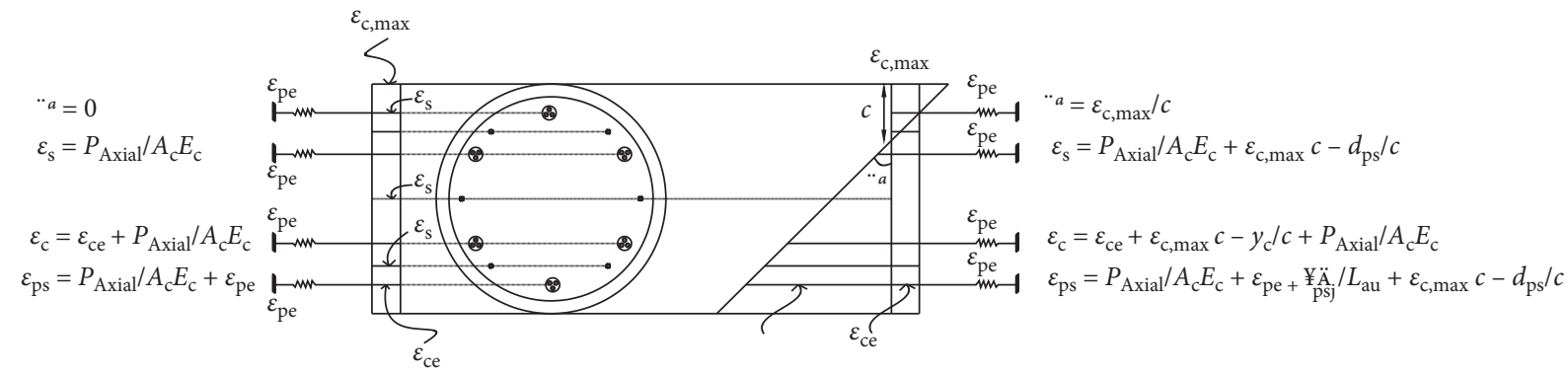

FIgURE 8: Conceptual diagram of M-Phi analysis. 


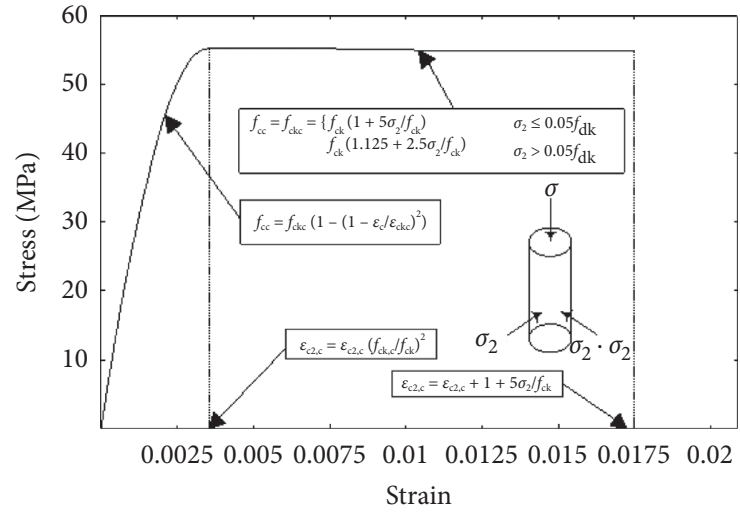

(a)

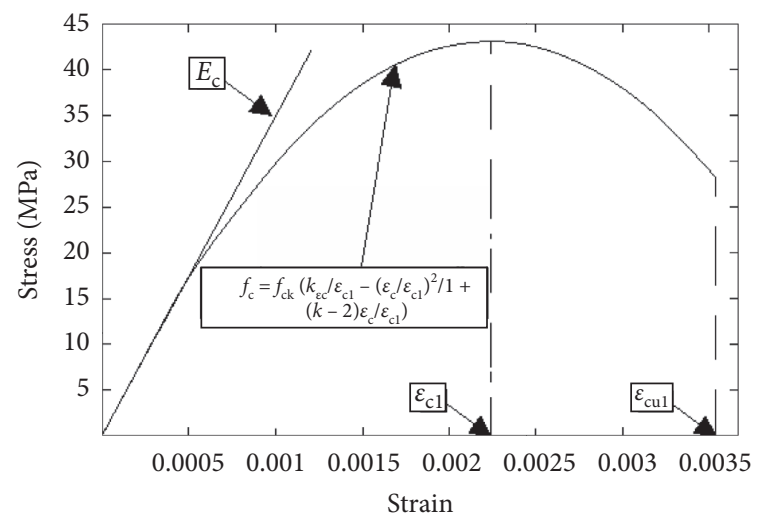

(b)

Figure 9: Material curve of concrete. (a) Confined concrete. (b) Unconfined concrete.

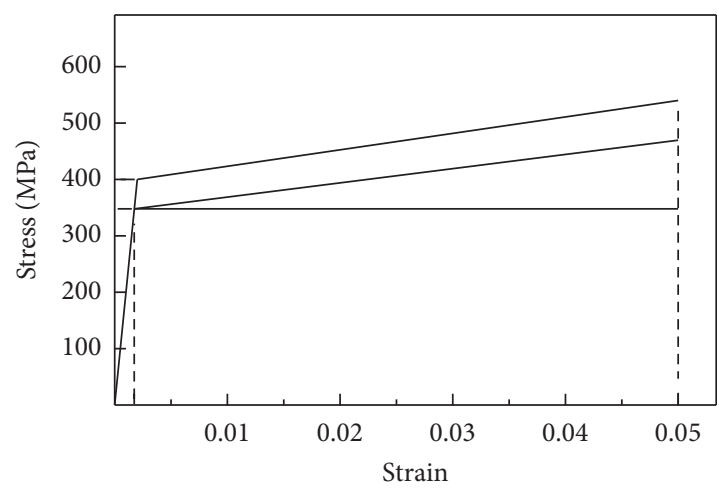

(a)

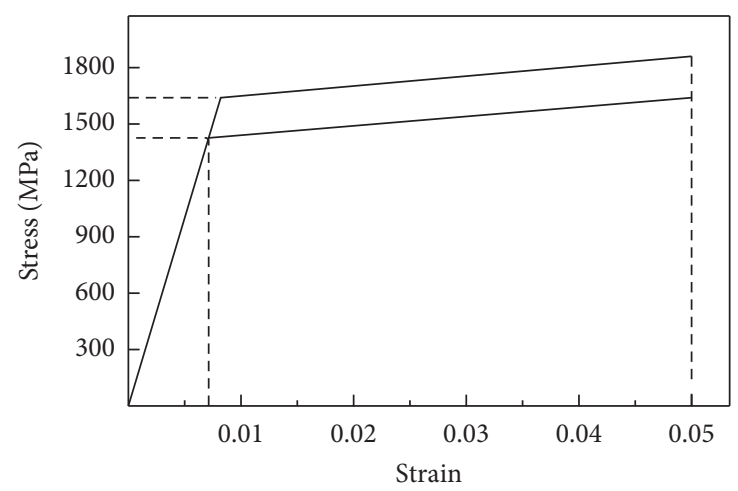

(b)

FIgURE 10: Material curves of axial steels according to Eurocode 2. (a) Reinforcement. (b) Tendon.

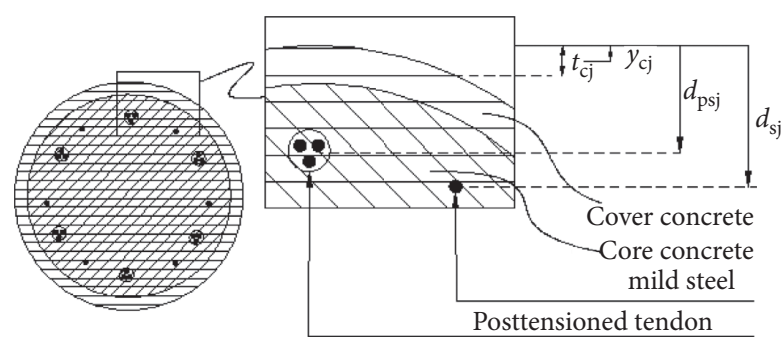

FIGURE 11: Section properties.

ratio of introduced prestress force to the ultimate strength, compressive strength of concrete, and spacing of transverse reinforcements, respectively.

Quantitative seismic performance at levels 1-4 of precast bridge pier with continuous reinforcement as given in Table 3 has been verified through analysis of M-Phi and quasistatic experiment. A parametric study was conducted to analyze the influence of effective prestress, spacing of transverse reinforcement, and strength of concrete on each level of seismic performance within designable range.
Prestress or $f_{\mathrm{pj}}$ could be introduced at up to $94 \%$ of yield strength, and when approximately $15 \%$ loss is considered, $f_{\mathrm{pe}}$ is at around $80 \%$ of yield strength. Because a $5 \%$ margin is made for safety, the upper bound is set to $75 \%$ and deducts every $10 \%$. For transverse reinforcement, it was composed between $40 \mathrm{~mm}$ and $192 \mathrm{~mm}$, taking the spacing and upper/ lower bounding value of confining reinforcement for core concrete. Concrete strength requires compressive strength over $35 \mathrm{MPa}$ in the case of introduction of prestress and sets $40-80 \mathrm{MPa}$ as a possible variable. 


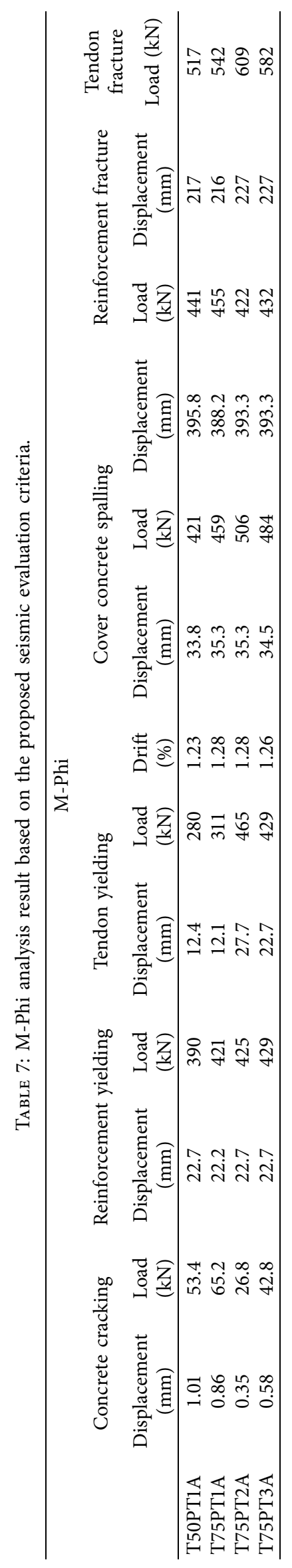




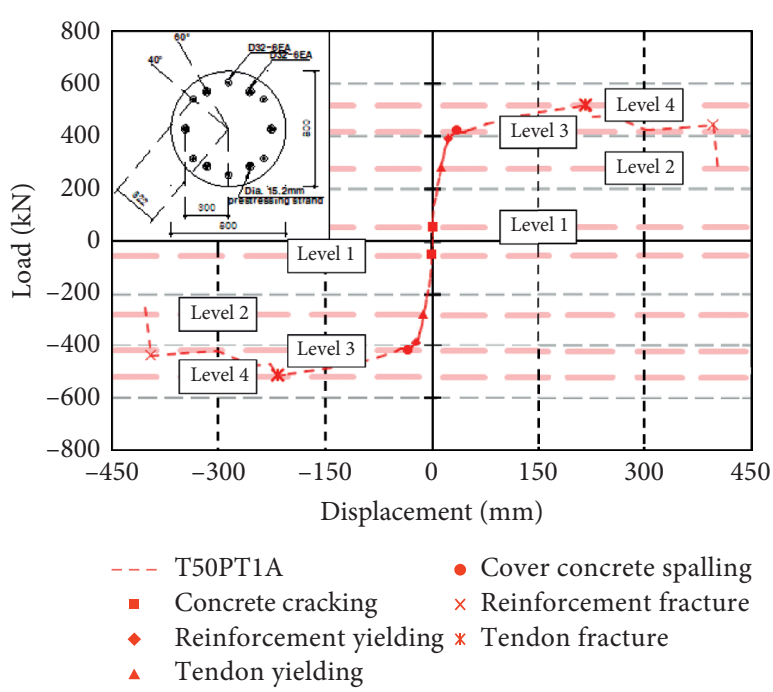

(a)

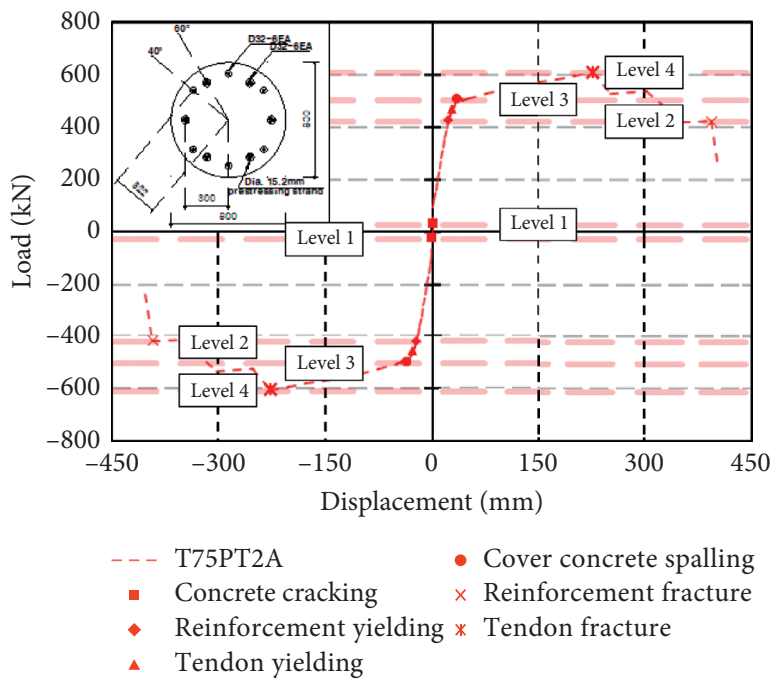

(c)

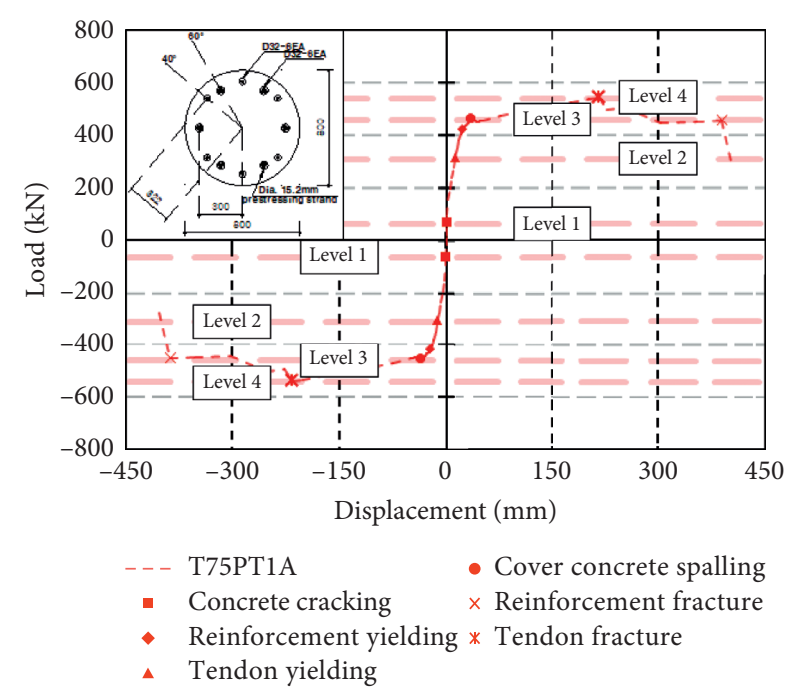

(b)

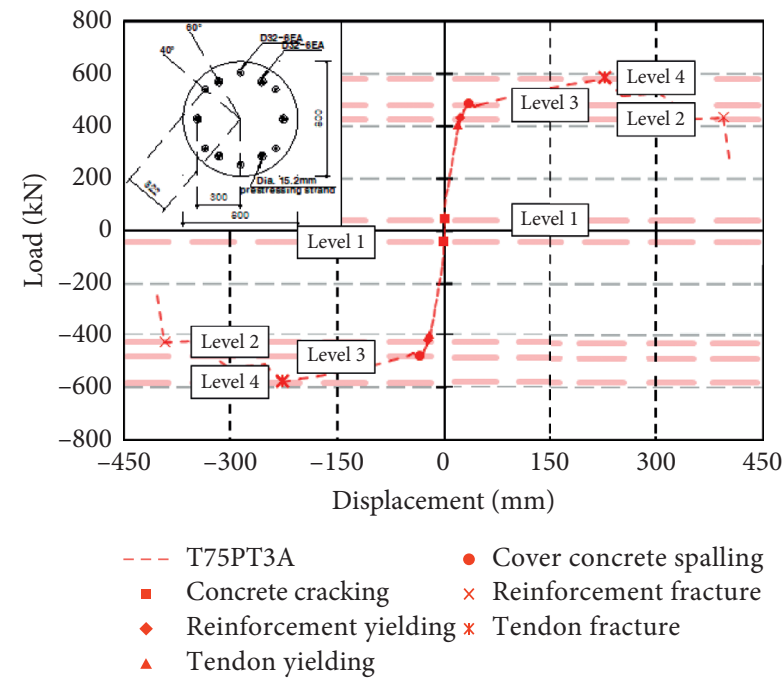

(d)

Figure 12: Load-displacement envelope curve by M-Phi analysis with performance level. (a) T50PT1A. (b) T75PT1A. (c) T75PT2A. (d) T75PT3A.

5.2. Effect of Introduction of Transverse Tendon. Introduced stress of prestress at $55-75 \%$ magnitude was focused upon in the parametric study and is shown in Figure 15(a). Under the codes given in Table 3, the results of evaluation are summarized in Table 8 . The results show that bridge piers of $55 \%$ magnitude of prestress showed $4.6 \%$ higher maximum strength than bridge piers of $75 \%$ magnitude of prestress. Introducing $75 \%$ of tension until it reaches $75 \%$ of maximum load showed $36.5 \%$ higher hardness than that of introducing $55 \%$ of tension. Bridge piers of $75 \%$ magnitude of prestress showed an initial crack at $14.6 \%$ higher level of load than that of bridge piers of $55 \%$ magnitude of prestress. Increase in the magnitude of prestress was shown to delay the arrival of level 1 of seismic performance. Bridge piers introduced with $75 \%$ prestress were observed to have continuous reinforcement yield at $14.7 \%$ lower load level than that of bridge piers introduced with 55\% prestress. The lower magnitude of prestress was shown to delay the arrival of level 2 of seismic performance. Spalling of cover concrete caused by magnitude of prestress showed no influence on the strength. In terms of displacement, bridge piers with $75 \%$ introduced prestress demonstrated a $17.7 \%$ lower displacement. As the magnitude of prestress increases, arrival at level 3 of seismic performance was observed to occur earlier. Increase in the magnitude of prestress was determined to increase stiffness for each level up to level 3 of seismic performance. The bridge pier with $75 \%$ introduced prestress was observed to reach level 4 of seismic performance at $13.3 \%$ lower load level than that of the bridge pier with 55\% introduced prestress. Increases in the magnitude of prestress did reduce ultimate displacement but also decreased yield displacement and thereby showed no considerable tendency in terms of displacement ductility. Increase in the magnitude of 

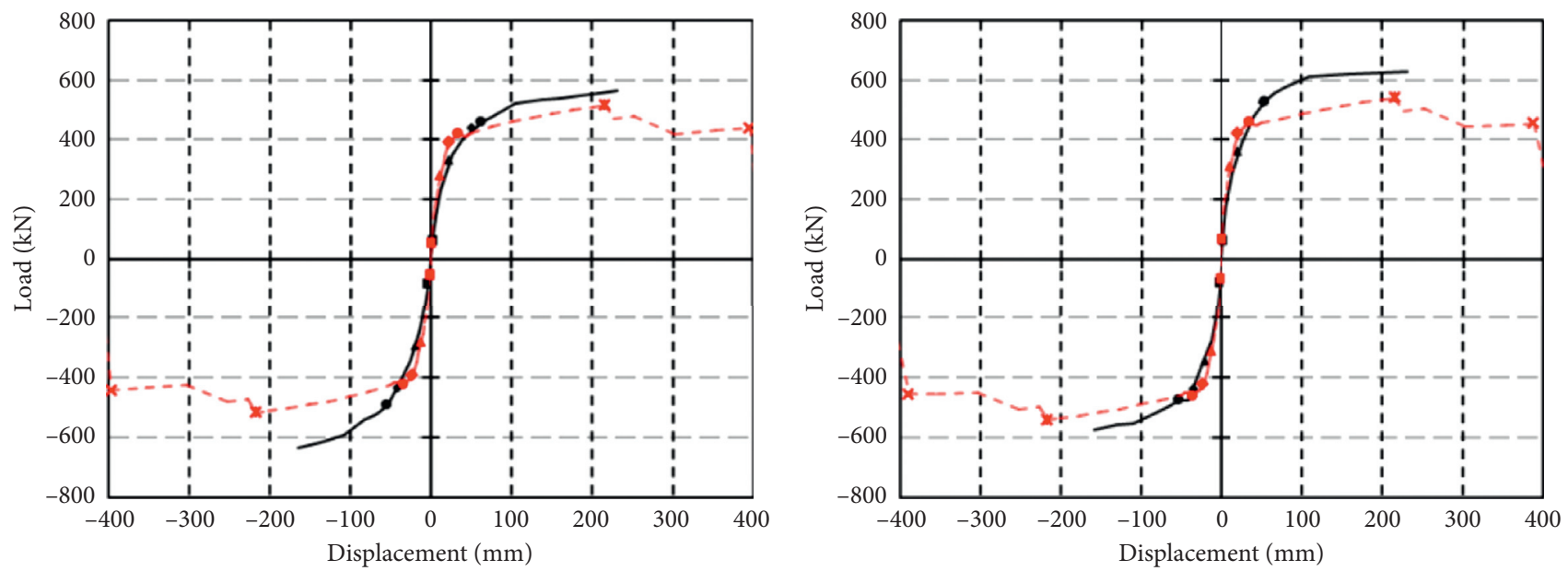

T50PT1A

- - - M-phi-envelope curve

- Test-envelope curve

- M-phi-concrete cracking

- Test-concrete cracking

- M-phi-reinforcement yielding

- Test-reinforcement yielding

- M-phi-tendon yielding

- M-phi-cover concrete spalling

- Test-tendon yielding

- Test-cover concrete spalling

$\times \quad$ M-phi-reinforcement fracture

* M-phi-tendon fracture

(a)
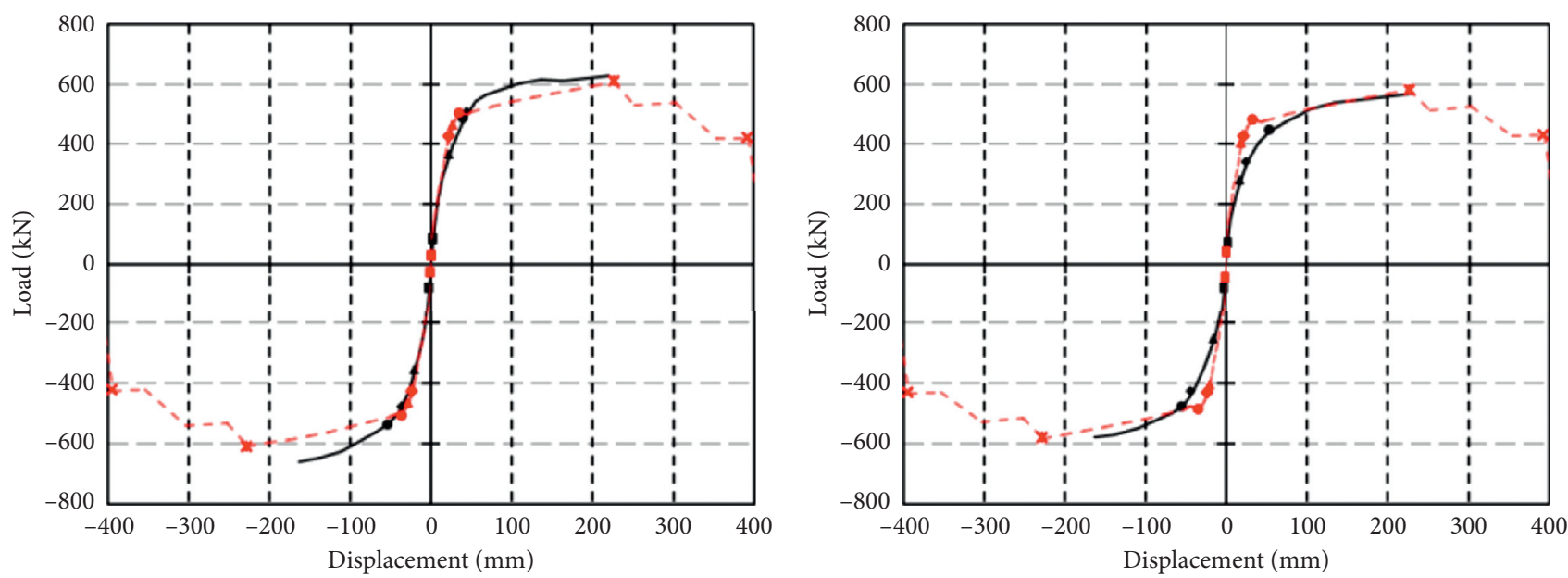

T75PT2A

- - M-phi-envelope curve

- M-phi-concrete cracking

- M-phi-reinforcement yielding

$\Delta \quad$ M-phi-tendon yielding

- M-phi-cover concrete spalling

Test-envelope curve

- Test-concrete cracking

- Test-reinforcement yielding

- Test-tendon yielding

- Test-cover concrete

M-phi-reinforcement spalling

fracture

* M-phi-tendon fracture

\section{T75PT1A}

- - - M-phi-envelope curve

M-phi-concrete cracking

M-phi-reinforcement yielding

A M-phi-tendon yielding

- M-phi-cover concrete spalling

- Test-envelope curve

- Test-concrete cracking

- Test-reinforcement yielding

- Test-tendon yielding

- Test-cover concrete spalling

$\times \quad$ M-phi-reinforcement fracture

* M-phi-tendon fracture

(b)

Triprax

- - - M-phi-envelope curve

- M-phi-concrete cracking

- M-phi-reinforcement yielding

- M-phi-tendon yielding

- M-phi-cover concrete spalling

$\times \quad$ M-phi-reinforcement fracture

* M-phi-tendon fracture

Figure 13: Load-displacement envelope curves from test and M-Phi analysis result. (a) T50PT1A. (b) T75PT1A. (c) T75PT2A. (d) T75PT3A. 


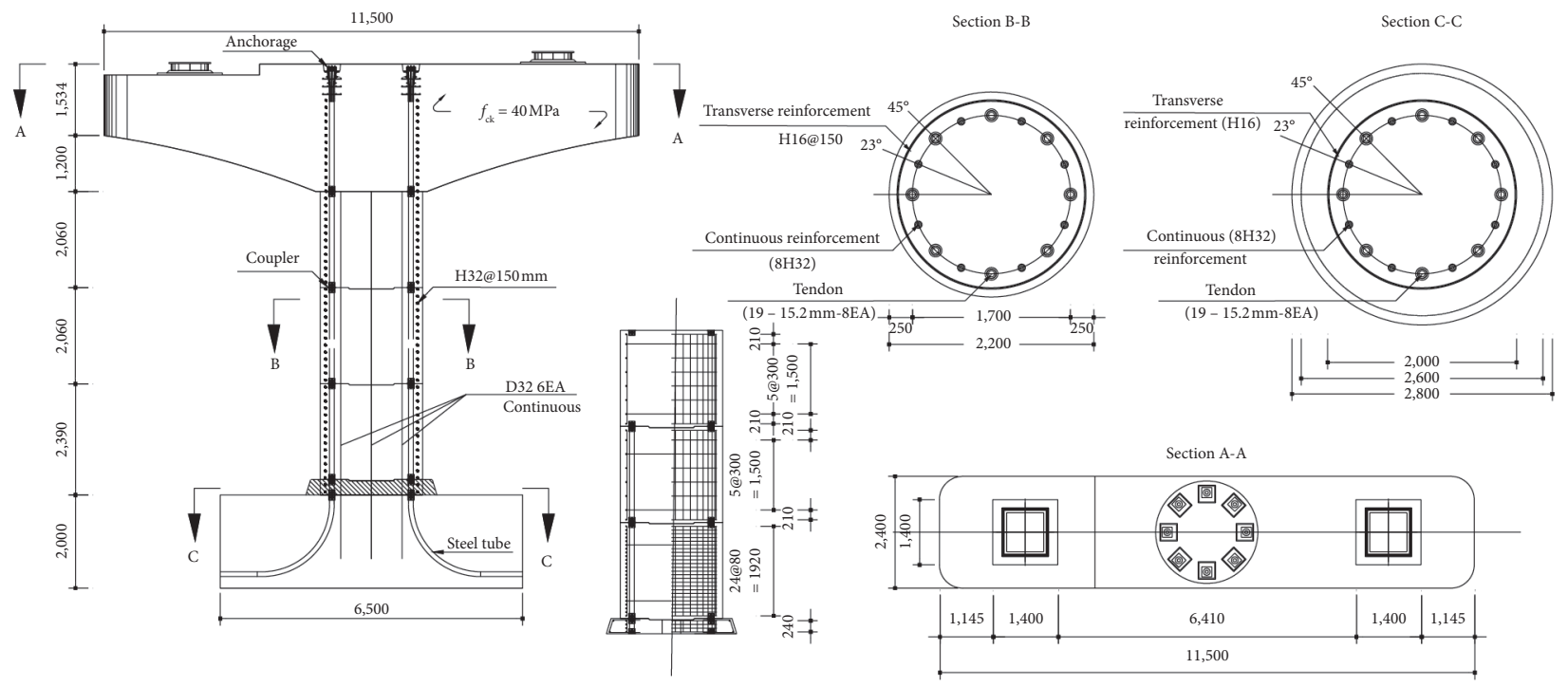

Figure 14: Detail of an example bridge pier.

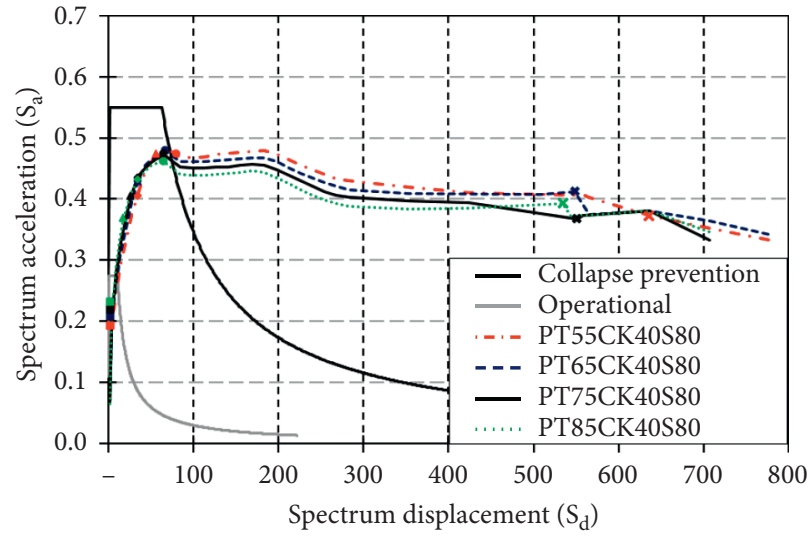

(a)

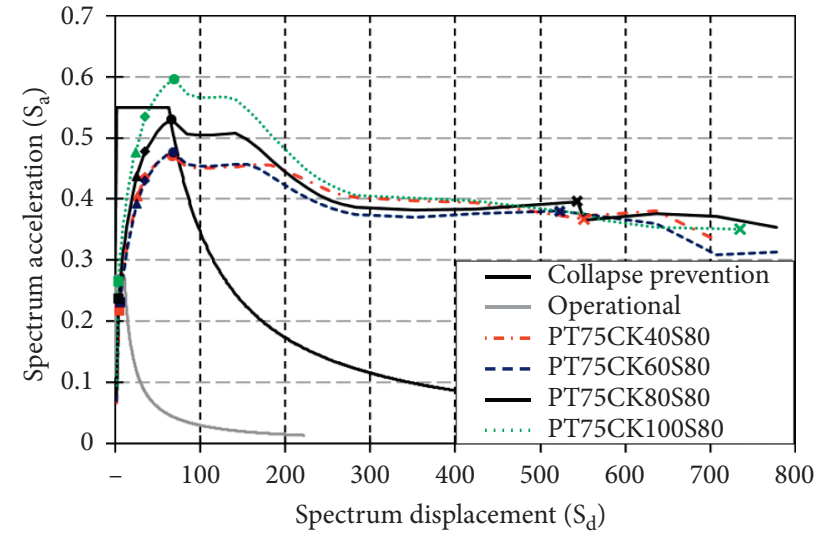

(b)

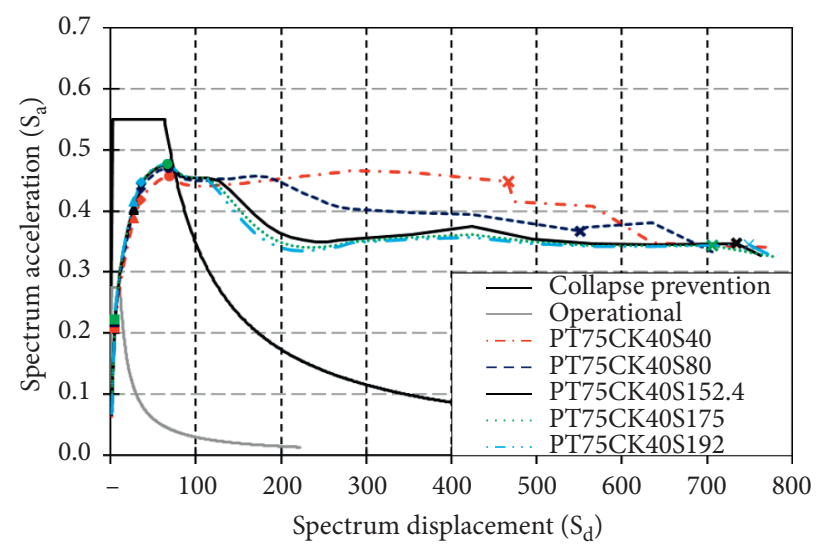

(c)

Figure 15: Parametric study of bridge piers. (a) Prestress. (b) Concrete strength. (c) Spacing of transverse reinforcement. 
TABLE 8: M-Phi analysis result based on the proposed seismic evaluation criteria for the real-scale bridge piers.

\begin{tabular}{|c|c|c|c|c|c|c|c|c|}
\hline & \multicolumn{2}{|c|}{ Concrete crack } & \multicolumn{2}{|c|}{ Concrete crushing } & \multicolumn{2}{|c|}{ Tendon yielding } & \multicolumn{2}{|c|}{ Tendon fracture } \\
\hline & $(\mathrm{kN})$ & $(\mathrm{mm})$ & $(\mathrm{kN})$ & $(\mathrm{mm})$ & $(\mathrm{kN})$ & $(\mathrm{mm})$ & $(\mathrm{kN})$ & $(\mathrm{mm})$ \\
\hline PT55CK40S80 & 1,786 & 4.0 & 4,402 & 82.0 & 4,439 & 56.5 & 3,502 & 635.9 \\
\hline PT65CK40S80 & 1,918 & 4.4 & 4,460 & 69.2 & 4,033 & 35.3 & 3,856 & 548.3 \\
\hline PT75CK40S80 & 2,046 & 4.7 & 4,406 & 67.5 & 3,786 & 26.6 & 3,440 & 551.1 \\
\hline PT75CK40S80 & 2,046 & 4.7 & 4,406 & 67.5 & 3,786 & 26.6 & 3,440 & 551.1 \\
\hline PT75CK60S80 & 2,160 & 5.7 & 4,467 & 68.4 & 3,676 & 25.4 & 3,563 & 522.8 \\
\hline PT75CK80S80 & 2,216 & 4.1 & 4,964 & 66.4 & 4,106 & 25.4 & 3,707 & 544.0 \\
\hline PT75CK40S40 & 1,951 & 4.7 & 4,286 & 69.2 & 3,638 & 26.8 & 4,203 & 466.3 \\
\hline PT75CK40S80 & 2,046 & 4.7 & 4,406 & 67.5 & 3,786 & 26.6 & 3,440 & 551.1 \\
\hline PT75CK40S152.4 & 2,073 & 4.7 & 4,455 & 66.4 & 3,765 & 27.0 & 3,248 & 734.8 \\
\hline PT75CK40S175 & 2,078 & 4.7 & 4,459 & 66.4 & 3,894 & 27.0 & 3,224 & 706.6 \\
\hline PT75CK40S192 & 2,082 & 4.7 & 4,463 & 66.4 & 3,896 & 26.8 & 3,230 & 748.9 \\
\hline
\end{tabular}

prestress was observed to delay the crack of concrete and allow spalling to occur earlier. It also resulted in premature yielding and fracture of strands. Evaluation on each level suggested in this paper showed that increase in the magnitude of prestress delays the time of arrival at level 1 , while accelerating those of levels 2,3 , and 4 .

5.3. Effect of Concrete Strength. The concrete strength underwent parametric study under the range of $40-80 \mathrm{MPa}$ with spacing of $20 \mathrm{MPa}$. The results of evaluation based on the codes listed in Table 3 are summarized in Table 8 . The case of $80 \mathrm{MPa}$ concrete strength showed $12.7 \%$ higher maximum strength, $6.0 \%$ higher hardness at the arrival of $75 \%$ maximum strength, and $41.5 \%$ lower result in terms of displacement ductility than that of the case of $40 \mathrm{MPa}$ concrete strength. The bridge pier of $80 \mathrm{MPa}$ concrete was observed to have an initial crack at $23.6 \%$ higher load level than the bridge pier of $40 \mathrm{MPa}$ concrete. Increase in the concrete strength was determined to delay the arrival at level 1 of seismic performance. Bridge piers of $80 \mathrm{MPa}$ concrete were shown to have continuous reinforcement yield at $8.1 \%$ higher load level than bridge piers of $40 \mathrm{MPa}$ concrete. Increase in the concrete strength was determined to delay the arrival at level 2 of seismic performance. Bridge piers of $80 \mathrm{MPa}$ concrete were observed to have cover concrete crushing at $11.3 \%$ higher load level than bridge piers of $40 \mathrm{MPa}$ concrete. Increase in the concrete strength was determined to delay the arrival at level 3 of seismic performance. Bridge piers of $80 \mathrm{MPa}$ concrete were shown to have continuous reinforcement fracture at $1.7 \%$ lower load level than that of bridge piers of $40 \mathrm{MPa}$ concrete. Increase in the concrete strength was determined to delay the arrival at level 4 of seismic performance. In terms of displacement, there were no evident impacts within structural behavior on crack and yielding of concrete, time of yielding, and fracture of strand. Bridge piers of $80 \mathrm{MPa}$ concrete were observed to have $23.6 \%$ higher strength at the crack of concrete, $11.3 \%$ higher strength at the yielding, $8.1 \%$ higher strength at the yielding of strand, and $1.7 \%$ lower strength at the fracture of strand than bridge piers of $40 \mathrm{MPa}$ concrete.

5.4. Impact of Spacing of Transverse Reinforcement. A parametric study on the spacing of transverse reinforcement between 40 and $192 \mathrm{~mm}$ was conducted and is expressed in Figure 15(c). Based on the codes listed in Table 3, the results are given in Table 8 . In terms of maximum strength, based on the minimum value, the maximum value showed a $2.3 \%$ difference. The impact of spacing of transverse reinforcement on the maximum strength could not be confirmed. Decrease in the spacing did apply in evaluation of highstrength confined concrete but showed no change in the maximum strength in the overall movement. In terms of displacement, when the reinforcements are placed with spacing of $40 \mathrm{~mm}, 3.56$ times higher displacement ductility and $4.2 \%$ lower maximum strength than that of $192 \mathrm{~mm}$ spacing were observed. Bridge piers with spacing of transverse reinforcement of $40 \mathrm{~mm}$ were observed to have the first crack of cover concrete at $6.7 \%$ higher load level than those with $192 \mathrm{~mm}$ spacing. Decrease in the spacing was determined to delay the arrival at level 1 of seismic performance. Bridge piers with spacing of $40 \mathrm{~mm}$ were shown to have continuous reinforcement yield at $4.1 \%$ higher load level than those with $192 \mathrm{~mm}$ spacing. Decrease in the spacing was determined to delay the arrival at level 2 of seismic performance. Bridge piers with spacing of $40 \mathrm{~mm}$ were observed to have cover concrete yield at $7.1 \%$ higher load level than those with $192 \mathrm{~mm}$ spacing. Decrease in the spacing was determined to delay the arrival at level 3 of seismic performance. Bridge piers with spacing of $40 \mathrm{~mm}$ were shown to have fracture at $32.2 \%$ higher load level than those with $192 \mathrm{~mm}$ spacing. Decrease in the spacing was determined to delay the arrival at level 4 of seismic performance in terms of displacement. A closer spacing does delay the arrival of $75 \%$ maximum strength and $85 \%$ maximum strength but showed leverage in terms of displacement ductility because of differences in degree of delay in yield displacement and ultimate displacement. With respect to the difference in the spacing of transverse reinforcement, the change in the time of concrete cracking, crushing, and yielding of strand showed no tendency. The arrival of strand's fracture was shown to be delayed.

5.5. Response Spectrum Analysis. Figure 16 shows the result of the conducted response spectrum with respect to Figure 15 by the level of individual performance according to the codes given in Table 5 . In level 1 (operational), increase 

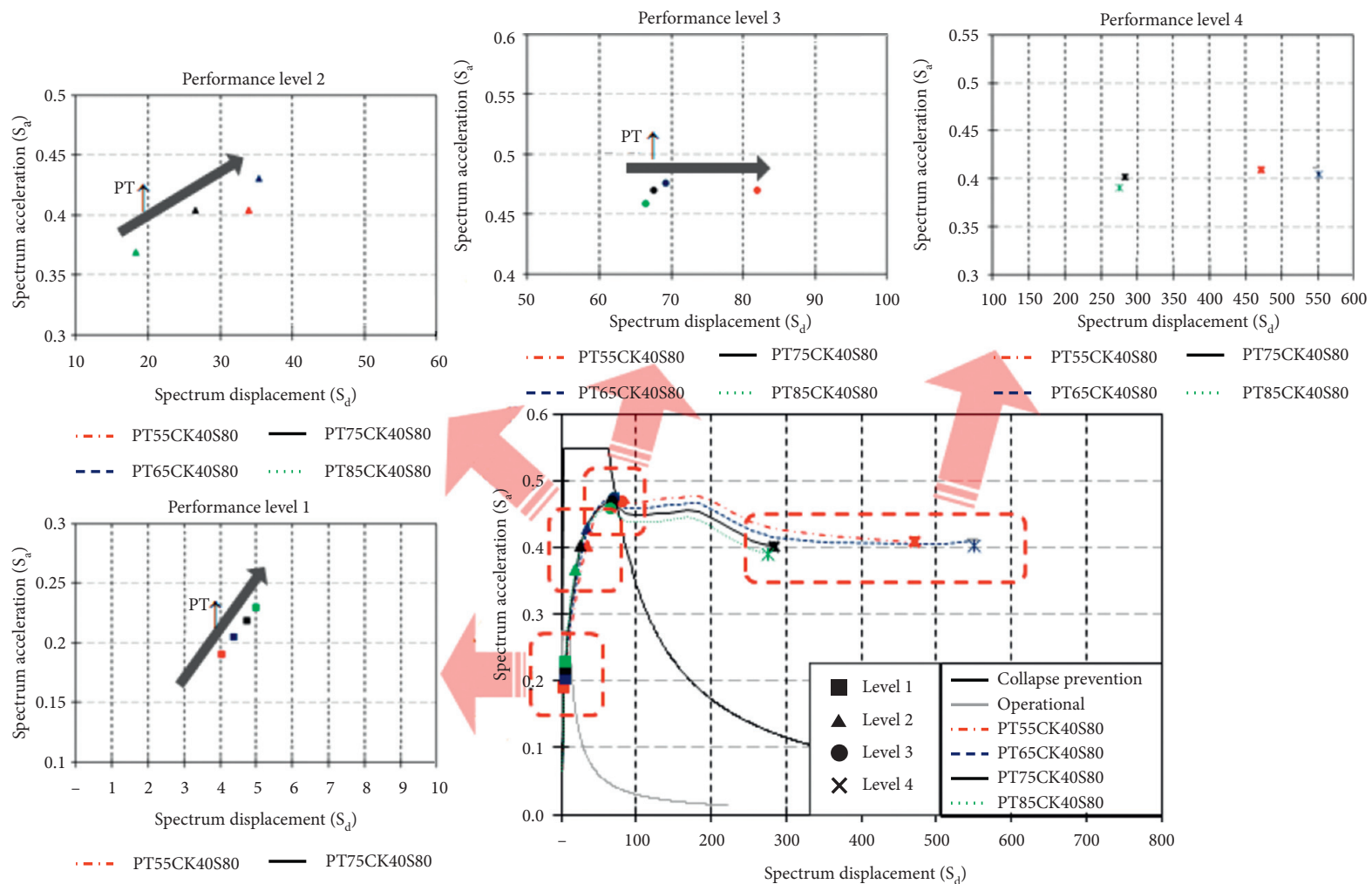

(a)
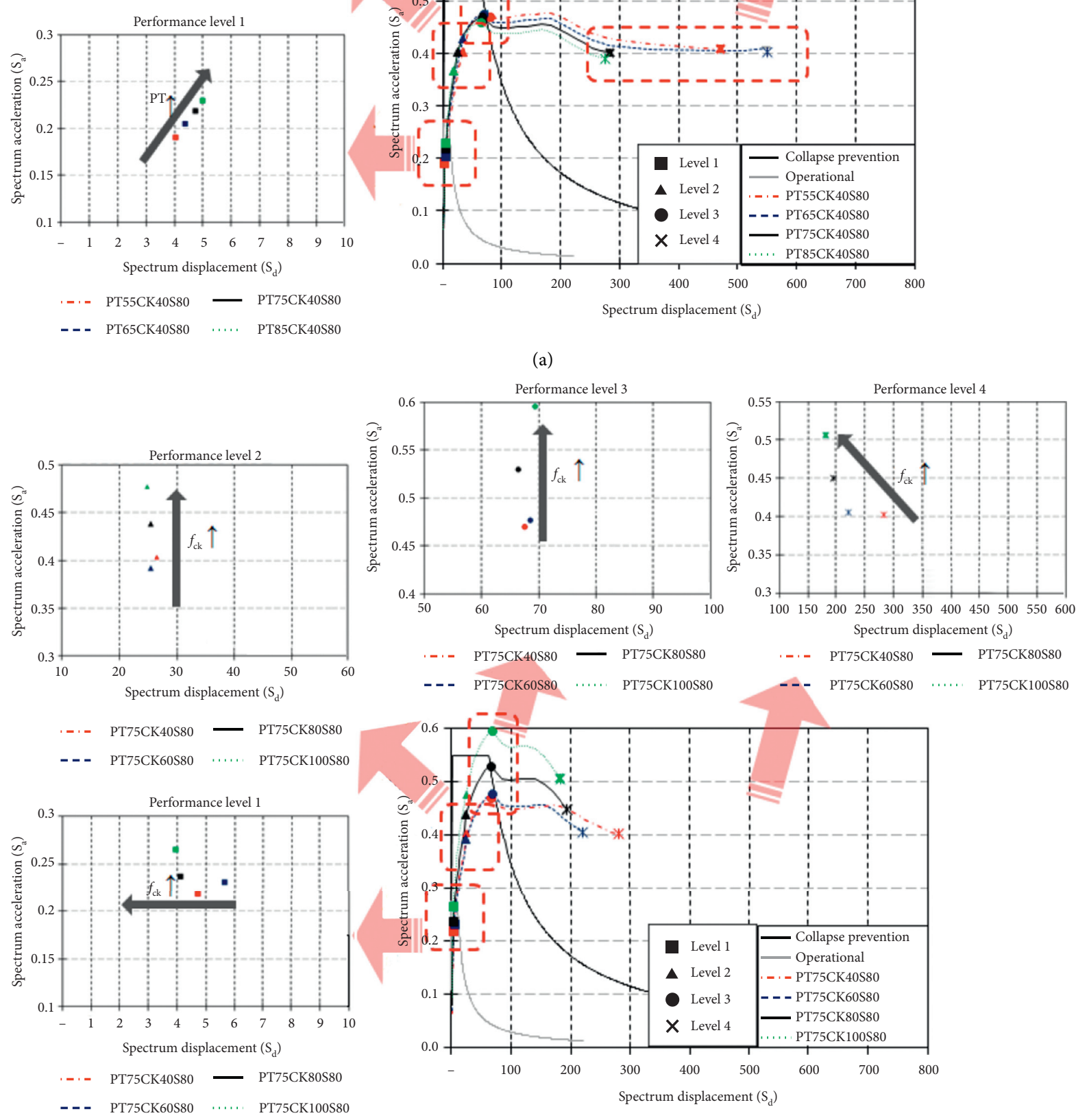

(b)

FIgURE 16: Continued. 

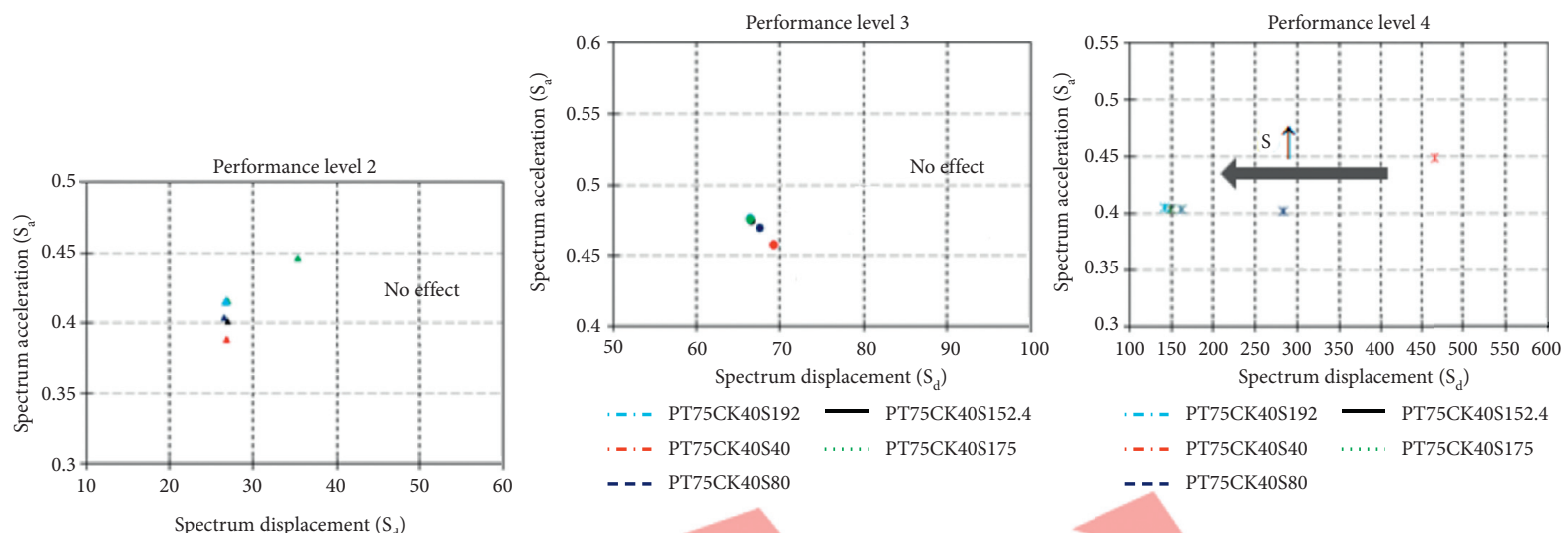

Spectrum displacement $\left(\mathrm{S}_{\mathrm{d}}\right)$

- . - PT75CK40S192 - PT75CK40S152.4

- - - PT75CK40S8

- - - PT75CK40S40

- - - PT75CK40S80

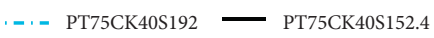

..-- PT75CK40S40 ….. PT75CK40S175

- - - PT75CK40S80
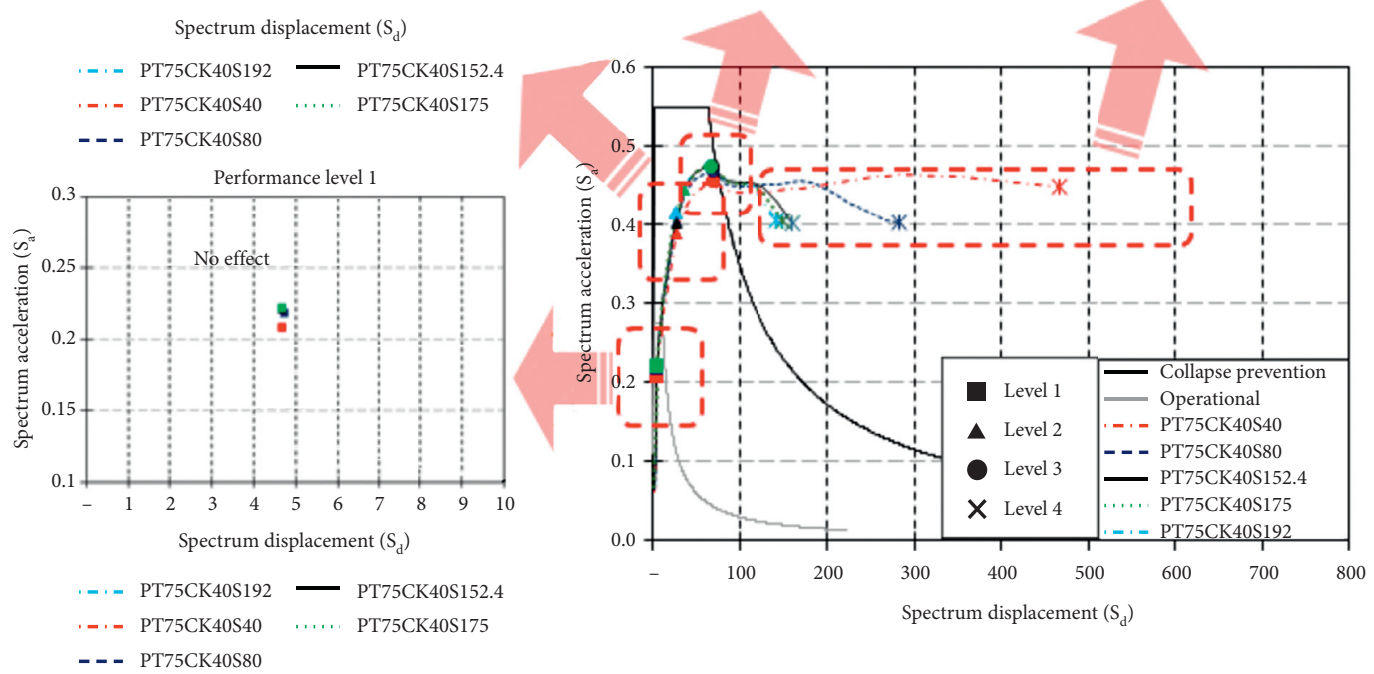

(c)

Figure 16: Response spectrum analysis. (a) Prestress. (b) Concrete strength. (c) Spacing of transverse reinforcement.

in the magnitude of prestress showed better results in terms of strength. Increase in the concrete strength showed desirable results in terms of strength and initial stiffness. No effect on the seismic performance was shown to be due to change in the spacing of transverse reinforcement. In level 2 (immediate occupancy), increase in the magnitude of prestress showed undesirable results in terms of stiffness and strength. Increase in the concrete strength showed desirable result in terms of strength and initial stiffness. No effect with respect to the change of spacing of transverse reinforcements was observed on the seismic performance. In level 3 (life safety), increase in the magnitude of prestress and change in the concrete strength showed no effect. Increase in the spacing of transverse reinforcement showed undesirable results in terms of stiffness. In level 4 (collapse prevention), increase in the magnitude of prestress showed undesirable result in terms of ductility. Increase in the concrete strength showed desirable result in terms of strength. A closer spacing of transverse reinforcement showed desirable result in terms of strength.

\section{Conclusion}

A quasistatic experiment on precast bridge piers has been conducted, and an analysis model for the simulation was constructed. Quantitative codes for evaluation of seismic performance of precast bridge piers have been suggested. A full-scale precast bridge pier was designed, and main influencing factors on seismic performance were examined. Precast bridge piers with structures of prestress introduced have undergone analytical research, and the results are as follows:

(1) Quantitative criteria for evaluation of seismic performance of precast bridge pier with structure of prestress being introduced, cracking of cover concrete, yielding of axial steels, and fracture of axial steels have been suggested.

(2) Using 4 small-sized specimens for quasistatic experiment and M-Phi analysis model, the 4 steps of seismic performance codes have been verified.

(3) Considering the safety and loss of prestress, $f_{\mathrm{pe}}$ is treated as a variable of strand's yield strength $55-75 \%$, and the result of analysis shows that the increase of prestress delays the arrival of level 1 of seismic performance up to $14.6 \%$. For levels 2, 3, and 4 , it is accelerated up to $14.7 \%, 17.7 \%$, and $13.3 \%$, respectively.

(4) Under the introduction of prestress, considering minimum compressive force, the compressive force 
of concrete is analyzed at $40-80 \mathrm{MPa}$, and each evaluation shows that increase in prestress delays arrival at levels 1,2 , and 3 up to $23.6 \%, 8.1 \%$, and $11.3 \%$, respectively. For arrival at level 4 , it is accelerated, and because of increase in strength, it showed a tendency to arrive early at below $85 \%$ of the minimum strength of bridge pier.

(5) Considering the maximum and minimum spacings of transverse reinforcement provided in the design code, the analysis is conducted under the setting of the variable within the range of $40 \mathrm{~mm}-192 \mathrm{~mm}$. Each evaluation reveals that there has not been evident regularity or tendency observed between change of spacing and arrival time at levels 1, 2, and 3 of seismic performance. The increase in the spacing has been shown to accelerate the arrival at level 4 of seismic performance in terms of displacement.

(6) Taking seismic performance of precast bridge pier with PSC structure into account, a parametric study on concrete strength, magnitude of prestress, and transverse reinforcement has been conducted, where the effect of the 3 variables on each level has been analyzed. The impact a change in a variable has on the corresponding level was analyzed through response spectrum.

\section{Data Availability}

The data used to support the findings of this study are included within the article.

\section{Conflicts of Interest}

The authors declare that they have no conflicts of interest.

\section{Acknowledgments}

This research was supported by a grant (13SCIPA01) from Smart Civil Infrastructure Research Program funded by Ministry of Land, Infrastructure and Transportation (MOLIT) of Korea government and Korea Agency for Infrastructure Technology Advancement (KAIA).

\section{References}

[1] American Association of State Highway Officials, LRFD Bridge Design Specifications, American Association of State Highway and Transportation Officials, Washington, DC, USA, 2007.

[2] G. Antonellis and M. Panagiotou, "Seismic response of bridges with rocking foundations compared to fixed-base bridges at a near-fault site," Journal of Bridge Engineering, vol. 19, no. 5, Article ID 04014007, 2013.

[3] R. M. Barker and J. A. Puckett, Design of Highway Bridges Based on AASHTO LRFD Bridge Design Specifications, Wiley, Hoboken, NY, USA, 1987.

[4] S. L. Billington, R. W. Barnes, and J. E. Breen, "Alternate substructure systems for standard highway bridges," Journal of Bridge Engineering, vol. 6, no. 2, pp. 87-94, 2001.
[5] CSA, Canadian Highway Bridge Design Code, CSA International, Ontario, Canada, 2006.

[6] Eurocode 8 (EC8), Design Provisions for Earthquake Resistance of Structures, Part 1- General Rules, Seismic Actions and Rules for Buildings, and Part 2-Bridges (European Prestandard), Eurocode, Brussels, Belgium, 2004.

[7] M. N. Sheikh, F. Legeron, and H. H. Tsang, "Seismic performance of bridges designed according to AS 5100," The Australian Earthquake Engineering Society Annual Conference, Gold Coast, Australia, 2012.

[8] K. Kawashima, G. A. MacRae, J.-i. Hoshikuma, and K. Nagaya, "Residual displacement response spectrum," Journal of Structural Engineering, vol. 124, no. 5, pp. 523-530, 1998.

[9] C. S. Shim, S. Y. Lee, S. J. Park, and C. Koem, "Cyclic tests on prefabricated bridge piers," in Proceeding of Advances in Structural Engineering and Mechanics, pp. 25-27, Brussels, Belgium, August 2015.

[10] C. Shim, S. Lee, S. Park, and C. Koem, "Experiments on prefabricated segmental bridge piers with continuous longitudinal reinforcing bars," Engineering Structures, vol. 132, pp. 671-683, 2017.

[11] S. J. Park, H. H. Song, and C. S. Shim, Experimental Research on Precast Bridge Piers with Details of Intermediate Anchorage of Prestressing Bars, Korea Concrete Institute Conference, Daejeon, South Korea, 2015.

[12] C. Koem, C.-S. Shim, and S.-J. Park, "Seismic performance of prefabricated bridge columns with combination of continuous mild reinforcements and partially unbonded tendons," Smart Structures and Systems, vol. 17, no. 4, pp. 541-557, 2016.

[13] S. J. Park, C. Koem, and C. S. Shim, "An experimental study on a concrete jacketing method for earthquake-damaged prefabricated bridge columns," Korea Concrete Institute Conference, vol. 28, no. 1, pp. 189-190, 2016.

[14] S. J. Park, C. Koem, J. S. Kim, and C. S. Shim, Evaluation of Seismic Performance of Precast Bridge Piers According to Performance Level, Korea Concrete Institute Conference, Daejeon, South Korea, 2018.

[15] M. Tazarv and M. S. Saiidi, "UHPC-filled duct connections for accelerated bridge construction of RC columns in high seismic zones," Engineering Structures, vol. 99, pp. 413-422, 2015.

[16] O. S. Haraldsson, T. M. Janes, M. O. Eberhard, and J. F. Stanton, "Seismic resistance of socket connection between footing and precast column," Journal of Bridge Engineering, vol. 18, no. 9, pp. 910-919, 2012.

[17] S. Motaref, M. S. Saiidi, and D. Sanders, "Shake table studies of energy-dissipating segmental bridge columns," Journal of Bridge Engineering, vol. 19, no. 2, pp. 186-199, 2014.

[18] E. E. Matsumoto, M. C. Waggoner, G. Sumen, and M. E. Kreger, "Development of a precast bent cap system," FHWA Rep. No. FHWA/TX-0-1748-2, Center for Transportation Research at the University of Texas, Austin, TX, USA, 2001.

[19] J. I. Restrepo, M. J. Tobolski, and E. E. Matsumoto, "Development of a precast bent cap system for seismic regions," Tech. Rep. 681, National Cooperative Highway Research Program, Washington, DC, USA, 2011.

[20] S. L. Billington and J. K. Yoon, "Cyclic response of unbonded posttensioned precast columns with ductile fiber-reinforced concrete," Journal of Bridge Engineering, vol. 9, no. 4, pp. 353-363, 2004.

[21] J. T. Hewes and M. J. N. Priestley, Seismic Design and Performance of Precast Concrete Segmental Bridge columns. 
Structural Systems Research Rep, University of California, San Diego, CA, USA, 2002.

[22] J. B. Mander, M. J. N. Priestley, and R. Park, "Theoretical stress-strain model for confined concrete," Journal of Structural Engineering, vol. 114, no. 8, pp. 1804-1826, 1988.

[23] I. Mantawy, T. Thonstand, D. H. Sanders, J. Stanton, and M. Eberhard, "Earthquake shake table testing of self-centering ABC bridge," in Proceedings of 2014 National Accelerated Bridge Construction Conference, A. Azizinamini and J. Gull, Eds., Florida International University, Miami, FL, USA, pp. 461-470, December 2014.

[24] M. Mashal, A. Palermo, and Z. Chegini, "Quasi-static cyclic tests of half-scale fully precast bridge bents incorporating emulative and posttensioned low damage solutions," in 2nd European Conference on Earthquake Engineering and Seismology, Turkish Earthquake Foundation, Istanbul, Turkey, January 2014.

[25] P. Koem, A. Aref, and A. Filiatrault, "Large-scale seismic testing of a hybrid sliding-rocking posttensioned segmental bridge system," Journal of Structural Engineering, vol. 40, no. 6, Article ID 04014025, 2014.

[26] W. Trono, G. Jen, M. Panagiotou, M. Schoettler, and C. Ostertag, "Seismic response of a damage-resistant recentering posttensioned-HYFRC bridge column," Journal of Bridge Engineering, vol. 20, no. 7, Article ID 04014096, 2014.

[27] Y. Hose, P. Silva, and F. Seible, "Development of a performance evaluation database for concrete bridge components and systems under simulated seismic loads," Earthquake Spectra, vol. 16, no. 2, pp. 413-442, 2000.

[28] D. Lehman, J. Moehle, S. Mahin, A. Calderone, and L. Henry, "Experimental evaluation of the seismic performance of reinforced concrete bridge columns," Structural Engineering, vol. 130, no. 6, pp. 869-879, 2004.

[29] Y. D. Hose and F. Seible, Performance Evaluation Database for Concrete Bridge Components and Systems under Simulated Seismic Loads, Pacific Earthquake Engineering Research Center, Richmond, CA, USA, 1999.

[30] M. N. Sheikh and F. Légeron, "Performance based seismic assessment of bridges designed according to canadian highway bridge design code," Canadian Journal of Civil Engineering, vol. 41, no. 9, pp. 777-787, 2014.

[31] C. S. Shim, S. J. Park, and S. Y. Lee, "Construction of a highway bridge with precast piers having improved seismic performance," KSCE Journal of Civil Engineerings, vol. 65, no. 12, pp. 48-51, 2017.

[32] C. S. Shim, C. Koem, H. H. Song, and S. J. Park, "Seismic performance of repaired severely damaged precast columns with high-fiber reinforced cementitious composites," KSCE Journal of Civil Engineering, vol. 22, no. 2, pp. 1-11, 2018.

[33] C. S. Shim and C. Koem, "Determination of effective prestress of post-tensioned precast bridge piers," Journal of the Earthquake Engineering Society of Korea, vol. 20, no. 3, pp. 135-143, 2016.

[34] S.-K. Kook, "Basic design for earthquake resistance of typical bridges," Journal of the Computational Structural Engineering Institute of Korea, vol. 26, no. 1, pp. 49-57, 2013. 